\title{
A COMISSÃO DE DIREITOS HUMANOS E LEGISLAÇÃO PARTICIPATIVA (CDH) NO SENADO BRASILEIRO: um estudo sobre sua composição (2005-2018)
}

\author{
THE HUMAN RIGHTS COMMISSION AND PARTICIPATORY LEGISLATION \\ (HRC) IN THE BRAZILIAN SENATE: a study on its composition (2005-2018)
}

Jonatas Nogueira Aguiar Souza e Silva*

\begin{abstract}
Resumo
Tendo como base os estudos legislativos brasileiros, é perceptível que o Senado é deixado em segundo plano, uma vez que a maior parte dos estudos sobre o Legislativo brasileiro foca na Câmara dos Deputados. Todavia, há, nas últimas décadas, um crescente interesse pelo estudo do Senado, mesmo que ainda sejam minoritários em relação aos estudos sobre a primeira câmara. Este trabalho tem como objetivo analisar o perfil dos senadores que ingressam na Comissão de Direitos Humanos e Legislação Participativa (CDH) do Senado, com base em dados políticos, sociodemográficos, atuação profissional e expertise, demonstrando o perfil daqueles que compõem esta comissão e sua relação com o seu papel informacional e deliberativo. Esse levantamento será cotejado com a literatura que trata da questão das comissões no Brasil, isto é, como os elementos partidários, a questão da expertise e seniority se apresentam na referida comissão. Os dados foram coletados a partir dos Relatórios Anuais da Presidência do Senado e da seção de biografia dos senadores, existentes no site da própria casa legislativa. $\mathrm{O}$ recorte temporal proposto cobre o período que se estende da criação da referida comissão até a última legislatura completa.
\end{abstract}

Palavras-chave: Senado; Sistema de Comissões; Estudos Legislativos; Comissão de Direitos Humanos.

\begin{abstract}
On the basis of Brazilian legislative studies, it is noticeable the preference for the lower house, however, there is a growing interest on the senate, even though it is lesser than the interest for the lower house. The main objective of this essay is to analyze the profiles of senators who join the Human Rights and Participatory Legislation Commission of the lower house, based on political, socio demographic, professional and expertise data, demonstrating the profile of those who make up this committee and their relation to the informational and deliberative role. This survey will be compared with the bibliography that deals with the committee matters in Brazil, in other words, how the party elements, issues of expertise and seniority are shown in said committee. The data has been collected from the lower house presidency annual reports and the senators' biography section, existing on the legislature's own website. The proposed time frame covers the period that extends from the creation of the committee until the last complete legislature.
\end{abstract}

Keywords: Senate; Committee System; Legislative Studies; Human Rights Commission.

\footnotetext{
* Graduando em Ciências Sociais/UFPA/Brasil. E-mail: jonnyaguiar12@gmail.com.
} 
SOUZA E SILVA, Jonatas N. A. A comissão de direitos humanos e legislação participativa (CDH) no senado brasileiro: um estudo sobre sua composição (2005-2018). Caos - Revista Eletrônica de Ciências Sociais, João Pessoa, n. 23, p. 79 -112, jul./dez. 2019. Disponível em: https://periodicos.ufpb.br/ojs2/index.php/caos/index.

\section{Introdução}

O sistema bicameral brasileiro é caracterizado como forte devido à simetria e incongruência - que são eixos que fortalecem a formulação de leis -, decorrentes da semelhante ou igual capacidade legislativa e de métodos que distinguem a composição das casas, de forma a criar um sistema com maior caráter democrático, uma vez que "a dimensão política ou redistributiva induz à formação de consensos entre uma pluralidade de interesses, favorecendo a representação democrática" (ARAÚJO, 2012, p. 87). Ou seja, o bicameralismo fortalece o caráter da democracia de acordo com o seu grau de simetria e incongruência.

A força do bicameralismo do Brasil pode ser vista a partir dos dispositivos que fomentam a incongruência e a simetria apontados por Araújo (2012). Referente à incongruência, há 8 dos 11 dispositivos propostos por Araújo (2012, p. 98), sendo eles: 1) tamanho das câmaras, 2) sistema eleitoral, 3) tipo de lista, 4) magnitude média, 5) renovação eleitoral, 6) duração de mandato, 7) idade mínima exigida e 8) regras para suplência. Já sobre a simetria, os poderes referentes à produção legislativa de criação, emenda e veto são iguais, com ressalvas a atividades de cunho diplomático, financeiro e jurídico, que são de atribuição do Senado.

Apesar disso, é visto que o Senado é deixado em segundo plano, levando em consideração que a maioria dos estudos legislativo foca análise na Câmara dos Deputados. Isso se deve ao fato de a maioria das matérias aprovadas serem de origem do Executivo, e o próprio regimento definir que tais matérias devem ser analisadas primeiramente pela Câmara dos Deputados, isso faz com que esta Casa se torne alvo de maior interesse por parte dos pesquisadores. Porém, estudar o Senado é de suma importância: o fator de incongruência cria uma Câmara Alta distinta da Câmara dos Deputados, e os estudos acerca de uma Câmara não refletem a outra devido a esse fator, que além de distinguir as casas cria um aspecto de maior especialização no Senado, sendo ele categorizado como casa revisora, o que torna importante estudar tal papel. 
SOUZA E SILVA, Jonatas N. A. A comissão de direitos humanos e legislação participativa (CDH) no senado brasileiro: um estudo sobre sua composição (2005-2018). Caos - Revista Eletrônica de Ciências Sociais, João Pessoa, n. 23, p. 79 -112, jul./dez. 2019. Disponível em: https://periodicos.ufpb.br/ojs2/index.php/caos/index.

Nessa lógica de revisão pelo Senado, é fundamental estudar as comissões, visto que, como apontado por Santos (2002), estas detiveram grandes poderes a partir da Constituição de 1988. Assim, as comissões são os espaços deliberativos e proporcionais - as regras de composição destas incluem proporcionalidade com o Plenário, tornando-as mais democráticas - e temáticos, pois cada comissão trabalha com áreas específicas, e tem primazia em atuação deliberativa e informacional, tal como foi definido pela Constituição de 1988.

Desta forma, torna-se importante analisar as comissões permanentes e suas temáticas. Dentre elas, a Comissão de Direitos Humanos e Legislação Participativa $(\mathrm{CDH})$ se destaca por suas atribuições regimentais:

À Comissão de Direitos Humanos e Legislação Participativa compete opinar
sobre: I - sugestões legislativas apresentadas por associações e órgãos de
classe, sindicatos e entidades organizadas da sociedade civil, exceto partidos
políticos com representação política no Congresso Nacional; II - pareceres
técnicos, exposições e propostas oriundas de entidades científicas e culturais e
de qualquer das entidades mencionadas no inciso I; III - garantia e promoção
dos direitos humanos; IV - direitos da mulher; V - proteção à família; VI -
proteção e integração social das pessoas portadoras de deficiências e de
proteção à infância, à juventude e aos idosos; VII - fiscalização,
acompanhamento, avaliação e controle das políticas governamentais relativas
aos direitos humanos, aos direitos da mulher, aos direitos das minorias sociais
ou étnicas, aos direitos dos estrangeiros, à proteção e integração das pessoas
portadoras de deficiência e à proteção à infância, à juventude e aos idosos"
(BRASIL, 2019).

Como se pode notar a partir das atribuições da $\mathrm{CDH}$, a referida comissão é local de discussão e decisão de importantes temas vinculados aos direitos humanos e de minorias, o que a torna fundamental nesse âmbito e importante para análise. Desta forma, o presente artigo tem por objetivo analisar a $\mathrm{CDH}$ a partir da sua composição. Assim, buscamos apresentar o perfil político dos senadores que a compuseram/compõem com base em dados políticos (distribuição partidária, pertencimento à base do governo), sociodemográfico (região, idade, gênero), atuação profissional e expertise. Para cumprir esse objetivo, o artigo está dividido em duas partes, além desta introdução e das considerações finais. Na primeira, será discutido o papel do Senado dentro do arranjo institucional brasileiro: o presidencialismo de coalizão. Já na segunda, apresentar-se-ão 
SOUZA E SILVA, Jonatas N. A. A comissão de direitos humanos e legislação participativa (CDH) no senado brasileiro: um estudo sobre sua composição (2005-2018). Caos - Revista Eletrônica de Ciências Sociais, João Pessoa, n. 23, p. 79 -112, jul./dez. 2019. Disponível em: https://periodicos.ufpb.br/ojs2/index.php/caos/index.

os dados sobre a composição dos membros titulares da CDH no período de 2005 até 2018, isto é, do ano da criação da comissão até a última legislatura completa. Os dados foram coletados a partir dos Relatórios Anuais da Presidência do Senado e das informações biográficas dos Senadores disponíveis no site do Senado, e foram organizados a partir dos seguintes eixos: 1) composição partidária; 2) posição no eixo governo-oposição; 3) caráter regional da representação; 4) expertise, e 5) seniority. A partir desses dados é possível caracterizar essa comissão dentro dos principais elementos destacados pela literatura que trata de comissões no Brasil.

\section{O Senado no presidencialismo de coalizão brasileiro}

Para se estudar o Senado, antes de tudo se deve ter conhecimento do funcionamento do legislativo brasileiro, o presidencialismo de coalizão e suas implicações no funcionamento da Câmara Alta. O debate aqui será feito sobre o funcionamento do presidencialismo de coalizão a partir da "era” FHC, onde de fato houve o funcionamento do modelo. Como apontado por Power (2015, p. 37), "o presidencialismo de coalizão tem uma adesão bem melhor à realidade após 1995, durante a era Cardoso-Lula, do que em relação ao comparativamente caótico período democrático anterior".

$\mathrm{Na}$ promulgação da Constituição de 1988, dois pontos principais foram adicionados ao desenho institucional do presidencialismo brasileiro: o poder de legislar do presidente foi reforçado, assim como a centralização do poder decisório nos líderes partidários e colégio dos líderes. Sobre os poderes de agenda outorgados ao Executivo, destacam-se as Medidas Provisórias (MP), Poder de Veto (total e parcial), Pedido de Urgência (que acelera o trâmite da matéria), exclusividade em pautas administrativas e orçamentárias. Somado a isso, o Executivo ainda tem a sua disposição cargos no Executivo que podem ser utilizados para gerar um compartilhamento de agenda com os partidos que formam o governo e sua base de apoio legislativo, criando um aspecto de preponderância do Executivo, tendo ele poderes para incentivar e induzir um 
SOUZA E SILVA, Jonatas N. A. A comissão de direitos humanos e legislação participativa (CDH) no senado brasileiro: um estudo sobre sua composição (2005-2018). Caos - Revista Eletrônica de Ciências Sociais, João Pessoa, n. 23, p. 79 -112, jul./dez. 2019. Disponível em: https://periodicos.ufpb.br/ojs2/index.php/caos/index.

comportamento cooperativo dos parlamentares. Em suma, o sistema destacado tem como base as prerrogativas do Executivo em iniciar legislação, editar medidas provisórias (MPs), o aceleramento do processo legislativo (por meio do Pedido de Urgência), áreas de iniciativa exclusivas e sancionar as leis, podendo ou não aplicar vetos parciais e totais ${ }^{1}$, poderes estes dados ao Executivo pela constituição de 1988.

Somado aos poderes de agenda do Executivo, há também a centralização dos poderes decisórios nas mãos dos líderes partidários, o que reforça a disciplina partidária no plenário, pois com a capacidade de organizar as suas bancadas, os líderes partidários viram peça chave no presidencialismo de coalizão. Desta maneira, há um sistema legislativo com predominância do Executivo que necessita negociar com os líderes partidários, pois estes detêm o poder decisório centralizado no interior do Legislativo. Desta forma, como apontado por Limongi e Figueiredo (1998, p. 85), "o Executivo domina o processo legislativo porque tem poder de agenda e essa agenda é processada e votada por um poder legislativo organizado de forma altamente centralizada em torno de regras que distribuem direitos parlamentares de acordo com os princípios partidários".

A centralização do poder decisório nos líderes partidários se dá porque os Regimentos Internos de ambas as casas legislativas (Câmara dos Deputados e Senado) outorgam aos líderes poderes de controle da agenda do legislativo, o que os tornam influentes na tomada de decisão dentro das casas legislativas. Por conseguinte, "os regimentos internos consagram um padrão decisório centralizado em o que conta são os partidos" (LIMONGI; FIGUEIREDO, 1998, p. 91). Dessa forma, o Executivo necessita negociar com os líderes partidários para a efetivação da sua agenda, pois estes detêm o poder decisório centralizado.

Dentro desse contexto de poder decisório centralizado, vale destacar o funcionamento do bicameralismo brasileiro tendo como base os eixos de simetria e incongruência. A simetria refere-se às capacidades legiferantes dos parlamentares da

\footnotetext{
${ }^{1}$ Sendo a matéria de origem do Executivo, dificilmente este utilizará do veto total na proposta por ele mesmo formulada.
} 
SOUZA E SILVA, Jonatas N. A. A comissão de direitos humanos e legislação participativa (CDH) no senado brasileiro: um estudo sobre sua composição (2005-2018). Caos - Revista Eletrônica de Ciências Sociais, João Pessoa, n. 23, p. 79 -112, jul./dez. 2019. Disponível em: https://periodicos.ufpb.br/ojs2/index.php/caos/index.

Câmara e Senado, visto que ambas possuem semelhantes poderes legislativos: "No caso brasileiro, tanto os senadores quanto os deputados podem iniciar, modificar e vetar projetos de lei. Além disso, um projeto de lei tem que ser aprovado por ambas as Câmaras para ser efetivado. Sendo assim, a capacidade legislativa de ambas as Casas Legislativas do Brasil é igual" (RUBIATTI, 2017, p. 41). Nesse sentido, "quanto mais equilibrada a distribuição formal do poder político entre as duas câmaras, maior a simetria e, portanto, maior a força do bicameralismo" (ARAÚJO, 2012, p. 89). No tocante à incongruência, esta é delimitada pela diferença entre os processos eleitorais, a duração dos mandatos, a renovação parcial ou total das câmaras, sistema eleitoral proporcional e majoritário, quantidade de cadeiras em cada casa, experiência parlamentar, padrão de renovação e data das eleições.

Sendo assim, encontram-se duas casas com simétricos poderes legislativos e com diferentes atores, exigindo uma maior discussão das pautas, o que, por sua vez, poderia melhorar o conteúdo das matérias. Sobre o Senado, é importante destacar o perfil dos seus integrantes. Tendo como base a incongruência fomentada pelo bicameralismo, é perceptível uma clara distinção entre deputados e senadores. Em primeiro lugar, o sistema eleitoral majoritário para senadores acaba por reforçar a presença de parlamentares com maior experiência política, tornando assim o Senado um espaço de carreira política mais avançada, logo, a maioria dos senadores já teve passagem pelo Legislativo e/ou Executivo. Somado a isso, a diferença na duração dos mandatos também influencia no tocante a expertise dos senadores ( 8 anos para Senado e 4 para a Câmara). Já a distribuição proporcional do número de cadeiras por estado (3 por estado) restringe o número de senadores, deixando a articulação no Senado mais viável. Tais fatores tornam o Senado uma casa de elevada carreira política, com representantes experientes em cargos legislativos e/ou executivos, experiência profissional e idade avançada (decorrente de anos em carreira política). Sendo assim, o fator da incongruência gera um Senado experiente, o que fortalece o seu caráter de revisão, o que não significa dizer que a Câmara Alta brasileira também não tenha papel de iniciativa. Em suma, "no que tange à capacidade legislativa - entendida como possibilidade de participação efetiva no processo 
SOUZA E SILVA, Jonatas N. A. A comissão de direitos humanos e legislação participativa (CDH) no senado brasileiro: um estudo sobre sua composição (2005-2018). Caos - Revista Eletrônica de Ciências Sociais, João Pessoa, n. 23, p. 79 -112, jul./dez. 2019. Disponível em: https://periodicos.ufpb.br/ojs2/index.php/caos/index.

de criação e aprovação de leis -, a segunda Câmara do Brasil é forte, uma vez que é necessário que os projetos de lei passem por ela para que sejam efetivados" (RUBIATTI, 2017, p. 42).

\section{A Comissão de Direitos Humanos e Legislação Participativa a partir da sua composição}

No tocante à $\mathrm{CDH}$, torna-se necessário uma explicação acerca do funcionamento do Senado e suas comissões, pois, diante das prerrogativas do presidente da República, o Legislativo torna-se reativo:

Um Legislativo reativo é aquele que delega a iniciativa das proposições legais mais importante ao Executivo. A definição de agenda, assim como as prioridades no que tange à ordem de apreciação dos projetos é transferida para o governo e negociada, posteriormente com os parlamentares que lideram o partido ou coalizão legislativa majoritária (SANTOS; ALMEIDA, 2011, p. 21).

Todavia, dentro de cada matéria de origem do Executivo há mudanças ocasionadas pelos dispositivos parlamentares, estas são as emendas adicionadas aos Projetos de Lei Ordinários (PL), Projetos de Lei Complementar (PLP) e as Medidas Provisórias (MP), sendo uma forma efetiva de participação dos parlamentares na atividade legislativa. Como apontado por Freitas (2016), as comissões exercem papel chave nesse processo de alteração das proposições feitas no interior do legislativo, mesmo que elas possam ser “contornadas" pelos Pedidos de Urgência. Somado a isso, é visto que majoritariamente as alterações ocorrem dentro das comissões: respectivamente $62 \%$ e $80 \%$ das PLs e PLPs são apresentados e deliberados no interior da comissão, demonstrando que o poder da urgência não altera o propósito das comissões (FREITAS, 2016). Ainda nesse contexto, sobre as urgências, mesmo estas, em tese, acelerando o trâmite da matéria, não fazem diminuir o número de dispositivos alterados pelos legisladores:

O que se verifica é que a ocorrência ou não de urgência não afeta o número de alterações realizadas no Legislativo, ao contrário, projetos com urgência são mais alterados do que os sem urgência. Nesse particular, não importando o tipo de urgência, os parlamentares continuam a exercer seu poder de deliberar e modificar as propostas (FREITAS, 2016, p. 77). 
SOUZA E SILVA, Jonatas N. A. A comissão de direitos humanos e legislação participativa (CDH) no senado brasileiro: um estudo sobre sua composição (2005-2018). Caos - Revista Eletrônica de Ciências Sociais, João Pessoa, n. 23, p. 79 -112, jul./dez. 2019. Disponível em: https://periodicos.ufpb.br/ojs2/index.php/caos/index.

Dentro do cenário de centralização do poder decisório nas mãos dos líderes partidários e das prerrogativas do Executivo, é importante destacar a importância das comissões. Nessa lógica cabe destacar o estudo comparativo de Santos (2002), no qual diferencia as comissões nos dois períodos democráticos vividos no Brasil - 1946 a 1964 , e pós 1988 -, sendo caracterizados dois presidencialismos de coalizão: faccional e racionalizado, respectivamente. Santos (2002) aponta que no período 1946-64, o que se destacava era o interesse individual dos parlamentares, uma vez que não havia meios para coordenar as preferências, desta forma criava-se uma paralisia decisória, devido à busca insaciável por recursos para seus respectivos distritos eleitorais. Na constituição de 1988, essa realidade foi alterada: as lideranças partidárias foram dotadas de poderes para coordenar, ou mesmo contornar, os desejos individuais dos parlamentares. Tal aquisição resultou na disciplina partidária, que no cenário pós-88 é peça fundamental do funcionamento do presidencialismo de coalizão. Dessa forma, as comissões do pós-88 são formadas a partir das indicações das lideranças partidárias que, por causa da disciplina partidária, utilizam como critério principal a expertise para a composição das suas bancadas nas comissões, podendo ser esta expertise por profissão, que se aproxima da temática da comissão, ou por experiência adquirida na permanência prolongada na comissão.

Cabe destacar também o poder terminativo das comissões do Senado, poder que sanciona ou veta a matéria sem a necessidade de ir ao plenário. Adquirido na Constituição de 1988, o poder terminativo veio a somar o caráter descentralizador do plenário e centralizador no âmbito das comissões, visto que, nelas, as decisões ganhavam um novo lugar de debate. Dentro dessa lógica de produção nas comissões, é vista a plena atividade das comissões permanentes, tanto no âmbito positivo como no negativo:

Dos 1.525 projetos de lei ordinária apresentados na Câmara dos Deputados [...] apenas $28,6 \%$ deles foram aprovados ou rejeitados no Parlamento, totalizando 436 projetos. Desses, 147 foram aprovados e 289 foram rejeitados. A matéria rejeitada nas comissões foi $91 \%$ superior à matéria rejeitada em Plenário, valor significativo numericamente, enquanto que a matéria aprovada foi $6,5 \%$ maior nas comissões (AMARAL, 2011, p. 157-8). 
SOUZA E SILVA, Jonatas N. A. A comissão de direitos humanos e legislação participativa (CDH) no senado brasileiro: um estudo sobre sua composição (2005-2018). Caos - Revista Eletrônica de Ciências Sociais, João Pessoa, n. 23, p. 79 -112, jul./dez. 2019. Disponível em: https://periodicos.ufpb.br/ojs2/index.php/caos/index.

Dessa forma, é visto que as comissões desempenham o seu papel deliberativo, assim como o uso do seu poder conclusivo/terminativo, sendo nítido o poder negativo destas, de rejeitar matérias que não consideram viáveis.

Ao tratar de comissões, é importante citar o estudo de Pereira e Mueller (2000) que explica o funcionamento das comissões por duas teorias: informacional, cujo objetivo do parlamentar ao ingressar na comissão é o de adquirir expertise e trazer a diminuição das incertezas ao plenário, e a distributiva ${ }^{2}$, na qual as comissões serviriam quando os interesses estiverem alinhados com o Executivo, sendo-lhe um importante filtro de matérias, aprovando-as e vetando-as de acordo com os interesses do chefe do governo. Dessa forma, como a maior parte dos líderes sempre está na coalizão governamental (pois o presidente necessita de coalizão para governar, logo ele a fará com as maiores bancadas), a lógica é que as comissões são espaços majoritariamente do Executivo, e quando não, o pedido de urgência é utilizado, levando a matéria ao plenário, passando por cima da comissão.

Todavia, segundo Santos e Almeida (2011), o caráter reativo do legislativo brasileiro abre espaço para a teoria informacional nas comissões, que tendo a expertise, podem ser atores chaves na diminuição das incertezas do parlamentar médio, visto que este necessita se posicionar acerca de tal política pública chave para poder ter o retorno eleitoral, assim o autor destaca o caráter oposicionista das comissões, que por deterem a expertise acerca da pauta, buscam informar esse parlamentar médio, contra tal política do Executivo. Tendo em vista as duas perspectivas dos autores, é visível que as comissões, estando ou não na base do governo, desempenham seus papéis, tanto positivo quanto negativo para o Executivo.

\footnotetext{
${ }^{2} \mathrm{Na}$ visão distributiva, as comissões possibilitariam ganhos de troca aos seus membros, isto é, o controle sobre políticas e o acesso aos recursos na comissão garantiriam ao parlamentar o necessário para atender às demandas de seu eleitorado, potencializando seu sucesso na próxima eleição. Ao tratar do caso brasileiro, Pereira e Muller (2000) apontam a necessidade de se observar que, nesse caso, é necessário acrescentar o Executivo, uma vez que este poder concentra muitos dos recursos necessários para atender às demandas dos parlamentares.
} 
SOUZA E SILVA, Jonatas N. A. A comissão de direitos humanos e legislação participativa (CDH) no senado brasileiro: um estudo sobre sua composição (2005-2018). Caos - Revista Eletrônica de Ciências Sociais, João Pessoa, n. 23, p. 79 -112, jul./dez. 2019. Disponível em: https://periodicos.ufpb.br/ojs2/index.php/caos/index.

Destacada a importância das comissões, passemos a analisar a Comissão de Direitos Humanos e Legislação Participativa $(\mathrm{CDH})$, considerando sua composição partidária, regionalidade, idade, gênero, número de mandatos, ocupação das cadeiras (titular e suplente), escolaridade, profissões e experiência prévia.

Tabela 1 - Composição Partidária da CDH (porcentagens)

\begin{tabular}{llllll}
\hline & $\mathbf{2 0 0 5 - 2 0 0 6}$ & $\mathbf{2 0 0 7 - 2 0 1 0}$ & $\mathbf{2 0 1 1 - 2 0 1 4}$ & $\mathbf{2 0 1 5 - 2 0 1 8}$ & $\begin{array}{l}\text { Total } \\
\text { período }\end{array}$ \\
\hline PT & 20,9 & 14,5 & 19,2 & 27,7 & $\mathbf{2 0 , 7}$ \\
MDB/PMDB & 25,6 & 23,7 & 16,4 & 16,9 & $\mathbf{2 0}$ \\
PSDB & 16,2 & 14,5 & 6,8 & 13,3 & $\mathbf{1 2 , 4}$ \\
DEM/PFL & 20,9 & 17,1 & 4,1 & 3,6 & $\mathbf{1 0 , 2}$ \\
PR & - & 6,6 & 8,2 & 8,4 & $\mathbf{6 , 5}$ \\
PDT & 4,7 & 7,9 & 5,5 & 2,4 & $\mathbf{5 , 1}$ \\
PSB & 2,3 & 2,6 & 5,5 & 4,8 & $\mathbf{4}$ \\
PTB & - & 2,6 & 9,6 & 2,4 & $\mathbf{4}$ \\
PMR/PRB & 4,7 & 2,6 & 5,5 & - & $\mathbf{2 , 9}$ \\
PSOL & - & 5,3 & 4,1 & 1,2 & $\mathbf{2 , 9}$ \\
PCdoB & 4,7 & 2,6 & 2,7 & - & $\mathbf{2 , 2}$ \\
PSD & - & - & 2,7 & 4,8 & $\mathbf{2 , 2}$ \\
PODE & - & - & - & 4,8 & $\mathbf{1 , 5}$ \\
PP & - & - & - & 4,8 & $\mathbf{1 , 5}$ \\
PV & - & - & 5,5 & - & $\mathbf{1 , 5}$ \\
PMN & - & - & 2,7 & - & $\mathbf{0 , 7}$ \\
REDE & - & - & - & 2,4 & $\mathbf{0 , 7}$ \\
PMB & - & - & - & 1,2 & $\mathbf{0 , 4}$ \\
PROS & - & - & - & 1,2 & $\mathbf{0 , 4}$ \\
PSC & - & - & 1,4 & - & $\mathbf{0 , 4}$ \\
\hline
\end{tabular}

Fonte: Elaboração própria a partir dos dados dos Relatórios Anuais da Presidência do Senado

Um primeiro ponto a se destacar é a distribuição partidária na comissão. Para tanto, apresentamos a tabela 1. Cabe notar que foram computadas todas as entradas de parlamentares na comissão, ou seja, não nos limitamos apenas aos membros indicados no início dos mandatos na comissão ${ }^{3}$, mas sim a todos os senadores que ocuparam vagas de titulares na $\mathrm{CDH}$.

Nesse caso, são vistas nos períodos analisados, características distintas dentro da comissão, isto é, há variações entre as diferentes legislaturas. No período final do primeiro

\footnotetext{
${ }^{3}$ Os mandatos nas comissões do Senado têm duração de dois anos.
} 
SOUZA E SILVA, Jonatas N. A. A comissão de direitos humanos e legislação participativa (CDH) no senado brasileiro: um estudo sobre sua composição (2005-2018). Caos - Revista Eletrônica de Ciências Sociais, João Pessoa, n. 23, p. 79 -112, jul./dez. 2019. Disponível em: https://periodicos.ufpb.br/ojs2/index.php/caos/index.

governo Lula (2005-2006), assim como no seu segundo mandato, há uma maior predominância do PT, PFL/DEM, PMDB e PSDB: juntos esses quatro partidos ocuparam $83,6 \%$ das vagas de titulares na $\mathrm{CDH}$. No tocante ao segundo mandato do presidente Lula, é visível uma fragmentação na composição da comissão, tendo ingressado nela dois novos partidos, o que reflete na diminuição da representação dos partidos preditos. Todavia, estes não deixam de apresentar maioria.

No tocante aos dois mandatos da presidenta Dilma, nitidamente é vista uma fragmentação partidária maior: enquanto no segundo governo Lula havia 11 partidos na composição da comissão, no primeiro e segundo mandato da presidenta Dilma, há 15 partidos compondo a comissão.

Outro ponto a se destacar no tocante à distribuição partidária das ocupações de cadeiras de titulares na $\mathrm{CDH}$ é o desempenho de alguns partidos. Os quatro partidos com maior número de indicações para essa comissão no total do período, são o PT, PMDB/MDB, PSDB e PFL/DEM. Entretanto, esses partidos apresentam diferentes trajetórias no período. Se no início do período analisado, o PMDB/MDB é responsável pelo maior número de indicados, nas duas últimas legislaturas analisadas, esse posto é ocupado pelo PT, que apresenta um crescimento nas suas indicações (saindo de 20,9\% e chegando a 27,7\%), enquanto cai o número de indicações do PMDB/MDB (de 25,6\% para 16,9\%). Por outro lado, o PSDB apresenta uma trajetória menos clara: cai nas legislaturas 2007-2010 e 2011-2014, mas volta a crescer na última, ainda que não recupere o mesmo índice de participação anterior. Somado a isso, nota-se uma forte queda na participação do DEM nessas legislaturas: se nos primeiros dois períodos, esse partido representava $20,9 \%$ e $17,1 \%$ dos membros que ocuparam cadeiras na comissão, nas duas legislaturas referentes aos governos de Dilma, e ao governo de Temer $^{4}$, essa participação cai para 4,1 e 3,6\%. Dessa forma, o PFL/DEM que ocupava a segunda posição (empatado com o PT) na participação nas indicações para membros titulares na $\mathrm{CDH}$ na primeira

\footnotetext{
${ }^{4}$ Michel Temer assume o cargo de presidente no meio da última legislatura, após o impeachment de Dilma Rousseff em 2016.
} 
SOUZA E SILVA, Jonatas N. A. A comissão de direitos humanos e legislação participativa (CDH) no senado brasileiro: um estudo sobre sua composição (2005-2018). Caos - Revista Eletrônica de Ciências Sociais, João Pessoa, n. 23, p. 79 -112, jul./dez. 2019. Disponível em: https://periodicos.ufpb.br/ojs2/index.php/caos/index.

legislatura, passa a ocupar a sétima posição entre os quinze partidos que indicaram membros entre 2015-2018.

De modo geral, a análise reflete dois períodos de governo do PT, registrando aumento crescente da participação de partidos pequenos, dando maior heterogeneidade à comissão e tornando-a um espaço deliberativo com maior abrangência partidária.

Devido ao multipartidarismo brasileiro, é comum o presidente da república formar coalizões de governo. Por esse motivo, cabe analisar a composição da CDH a partir da coalizão. Para fazer isso, utilizamos a base de dados do CEBRAP sob coalizões, utilizando o período temporal anual como unidade de análise. Após isso, observamos a participação desses partidos sobre o total dos membros da coalizão por ano. O gráfico 1 apresenta esse resultado. Nele também apontamos a participação do partido do chefe do Executivo: PT para o período entre 2005 e 2016, e PMDB/MDB para o restante do período.

Gráfico 1 - Participação do partido do Governo e da Coalizão na CDH (2005-2018)

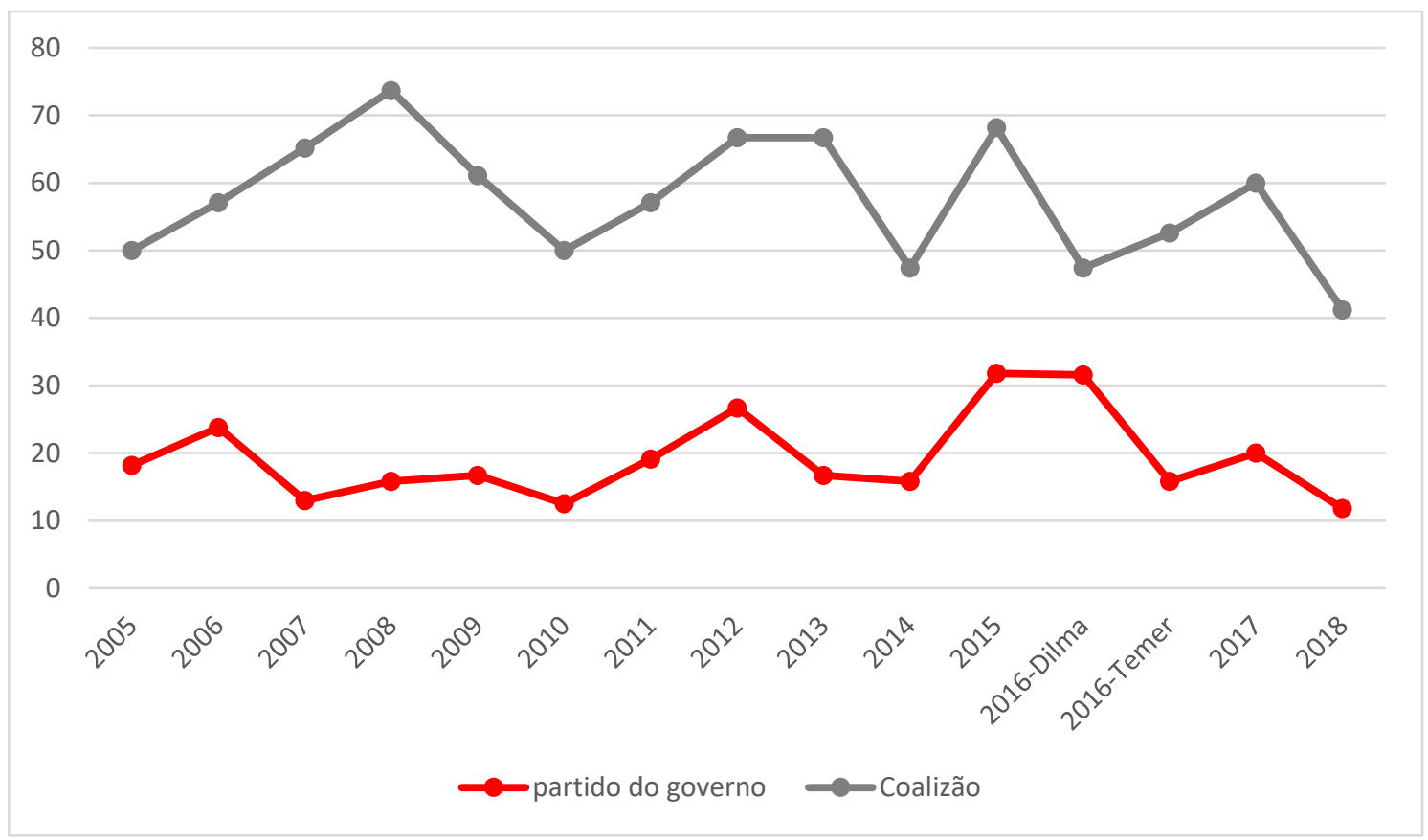

Fonte: Elaboração própria a partir dos dados dos Relatórios Anuais da Presidência do Senado 
SOUZA E SILVA, Jonatas N. A. A comissão de direitos humanos e legislação participativa (CDH) no senado brasileiro: um estudo sobre sua composição (2005-2018). Caos - Revista Eletrônica de Ciências Sociais, João Pessoa, n. 23, p. 79 -112, jul./dez. 2019. Disponível em: https://periodicos.ufpb.br/ojs2/index.php/caos/index.

Como mostra o gráfico 1 , dentro da comissão é notável a predominância da coalizão governamental, que somente declinou no final das legislaturas - momentos em que as coalizões enfraquecem devido à configuração de nova coligações eleitorais todavia não perdendo significativamente a maioria: apenas nos anos de 2014 (ano eleitoral), 2016 (no período de crise do governo Dilma Rousseff) e 2018 (final do governo Temer) a coligação governamental perde a maioria na $\mathrm{CDH}$, sendo que apenas na última fase, a coligação ficou abaixo de 45\%. Na linha da presença do partido do governo, verifica-se alternância significativa dentro da comissão, podendo ser explicada pela própria coalizão governamental, visto que esta taxa cresce no decorrer do mandato presidencial. É importante ressaltar o estudo de Muller (2005), afirma que os partidos mandam para as comissões os deputados que mais se alinham ao espectro ideológico do partido. Sendo os partidos base da coalizão, os seus espectros ideológicos tendem a assemelhar-se com o do partido do chefe do Executivo, respondendo assim a uma ocupação da coalizão maior, e menor participação do partido do governo.

Ainda sobre o partido do governo, vemos sua predominância no período do impeachment da Presidenta Dilma, em que ele manteve sua maior ocupação, acima de $30 \%$ nos dois anos (2015-2016), demonstrando que em período de crise governamental, o partido optou pela própria presença, talvez como mecanismo de defesa, baseado na lealdade partidária (visto que sua coalizão estava enfraquecida, fato notável no ano de 2016) ou podendo também estar respaldado nas regras internas do próprio Senado (RISF), que determinam que as decisões dentro das comissões são definidas de forma majoritária, dessa maneira, a maior participação do partido do presidente assegura menor incerteza de perda de quórum diante de pautas de interesse do governo. Sendo assim, a composição da $\mathrm{CDH}$ foi guiada pelo interesse do governo em ocupá-la majoritariamente. Este caso aproxima-se da teoria informacional conforme Pereira e Mueller (2000), na qual se apresenta a lógica da preponderância do Executivo funcionando com as comissões alinhadas ideologicamente ao governo, fazendo não ocorrer a urgência - comportamento mais visível em coalizões de mesmo espectro ideológico - devido ao fato do ganho informacional ser melhor que o aceleramento de uma política com incertezas, permitindo 
SOUZA E SILVA, Jonatas N. A. A comissão de direitos humanos e legislação participativa (CDH) no senado brasileiro: um estudo sobre sua composição (2005-2018). Caos - Revista Eletrônica de Ciências Sociais, João Pessoa, n. 23, p. 79 -112, jul./dez. 2019. Disponível em: https://periodicos.ufpb.br/ojs2/index.php/caos/index.

à comissão diminuir as incertezas no plenário, produzindo uma política pública, tendo noção da sua consequência.

Gráfico 2 - Representação regional na CDH

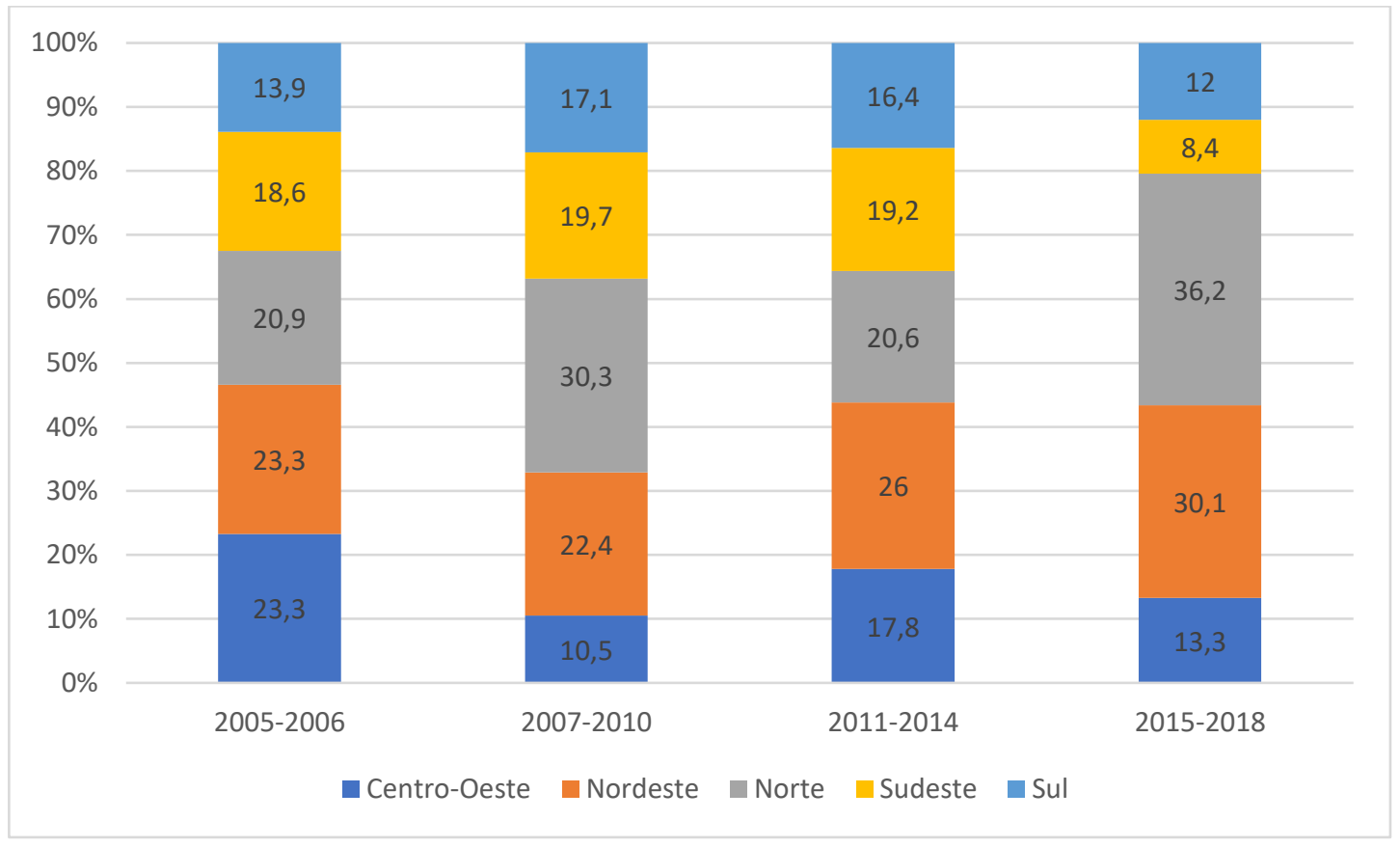

Fonte: Elaboração própria a partir dos dados dos Relatórios Anuais da Presidência do Senado

No tocante à região, é visto que em 2005-2006, as regiões Centro-oeste e Nordeste concentram a maior participação na comissão. Esse quadro muda em 2007-2010: a maior concentração refere-se ao Norte e Nordeste, com uma significativa queda na porcentagem do Centro-oeste, sendo a região Norte sobrerepresentada em comparação ao Nordeste. Tal representação é alterada de novo no período de 2011-2014, tendo agora a maioria, os estados do Nordeste seguidos pelos do Norte com a segunda maior representação. Entre 2015-2018, o Norte volta a ocupar o primeiro lugar entre os titulares da comissão (36,2\%), sendo a maior representação desde o período de criação da comissão. Atrás dele está o Nordeste com $30,1 \%$, sendo esta também a sua maior representação na comissão. De forma geral, é visível o interesse por parte do Norte e Nordeste na comissão, é importante citar que o Sudeste também teve uma representação notória, sendo somente em 20152018 que sua participação foi de 8,7, o menor registro desde a criação da comissão. Cabe 
SOUZA E SILVA, Jonatas N. A. A comissão de direitos humanos e legislação participativa (CDH) no senado brasileiro: um estudo sobre sua composição (2005-2018). Caos - Revista Eletrônica de Ciências Sociais, João Pessoa, n. 23, p. 79 -112, jul./dez. 2019. Disponível em: https://periodicos.ufpb.br/ojs2/index.php/caos/index.

notar que a representação do Nordeste no plenário do Senado é a maior entre as regiões, por esse motivo sua participação na $\mathrm{CDH}$ pode apenas estar relacionada a este fator. Da mesma forma, a região Norte detém o segundo maior número de cadeiras no plenário. Por isso, apesar da maior participação dos senadores dessas regiões na comissão, isso pode não significar um maior interesse dos parlamentares da região pela temática da $\mathrm{CDH}$, mas sim, ser apenas um reflexo da distribuição regional do plenário.

Gráfico 3 - Idade dos senadores que ocuparam vaga de titulares na $\mathrm{CDH}$

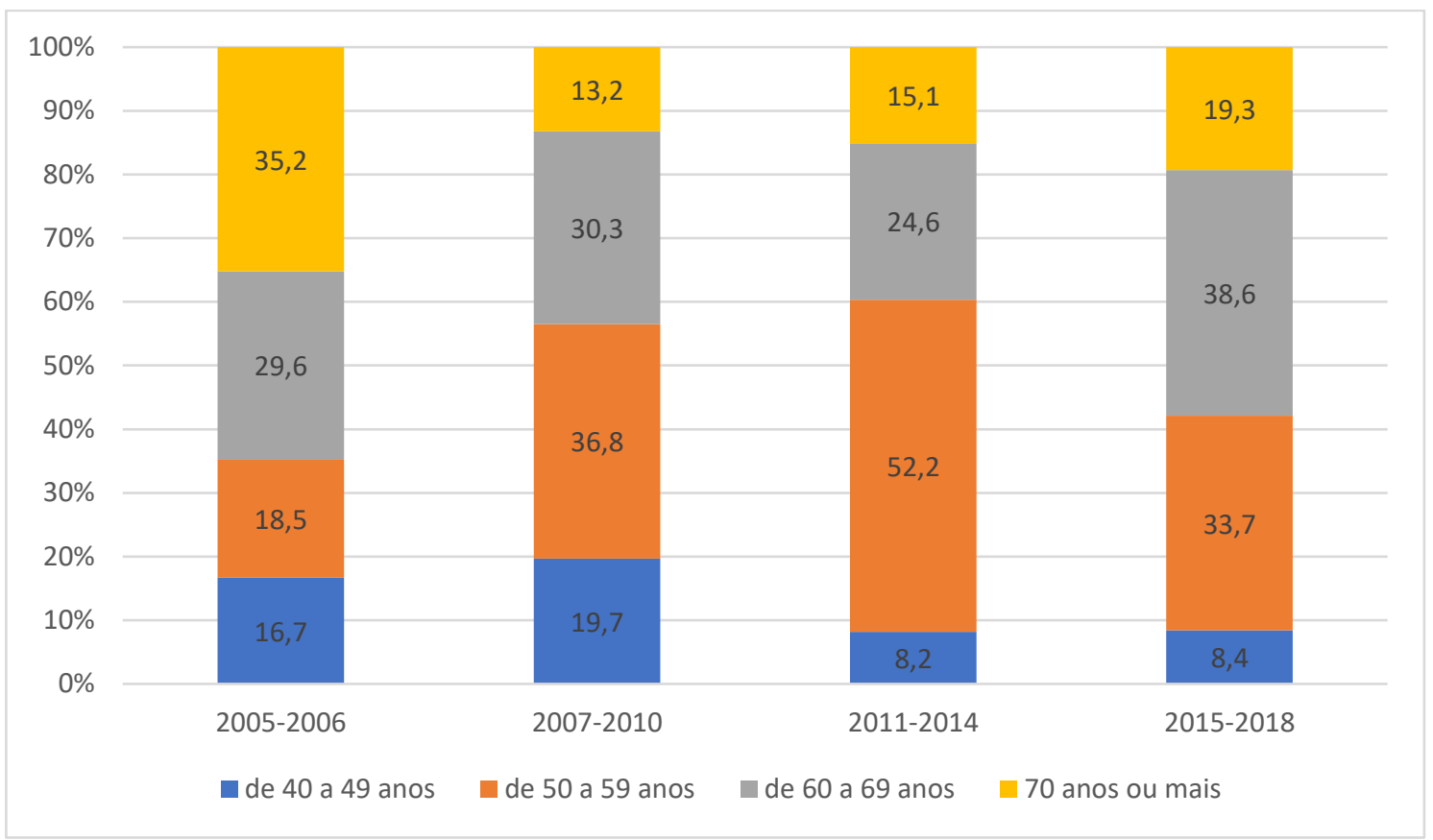

Fonte: Elaboração própria a partir dos dados dos Relatórios Anuais da Presidência do Senado

Outro elemento a se destacar é a idade dos senadores da CDH. A partir do gráfico 3, é notável uma primeira composição com elevada faixa etária, mas posteriormente isso muda: a maior frequência no primeiro período era de senadores com mais de 70 anos, e passa a ser a faixa de 50-59 anos nos períodos entre de 2007-2014, dando um caráter de regressão da idade, porém ainda dentro dos padrões esperados, pois como mostram Lemos e Renincheski (2008), em estudo semelhante ao nosso, cujo recorte temporal considerou os anos de 1990, sobre a composição da Comissão de Constituição e Justiça (CCJ), na qual a predominância era a faixa etária entre 50 e 59 anos de idade, alguns com mais de 
SOUZA E SILVA, Jonatas N. A. A comissão de direitos humanos e legislação participativa (CDH) no senado brasileiro: um estudo sobre sua composição (2005-2018). Caos - Revista Eletrônica de Ciências Sociais, João Pessoa, n. 23, p. 79 -112, jul./dez. 2019. Disponível em: https://periodicos.ufpb.br/ojs2/index.php/caos/index.

60 anos, o que representa a prevalência de maior experiência como critério de composição das comissões.

Gráfico 4 - Distribuição de gênero na CDH

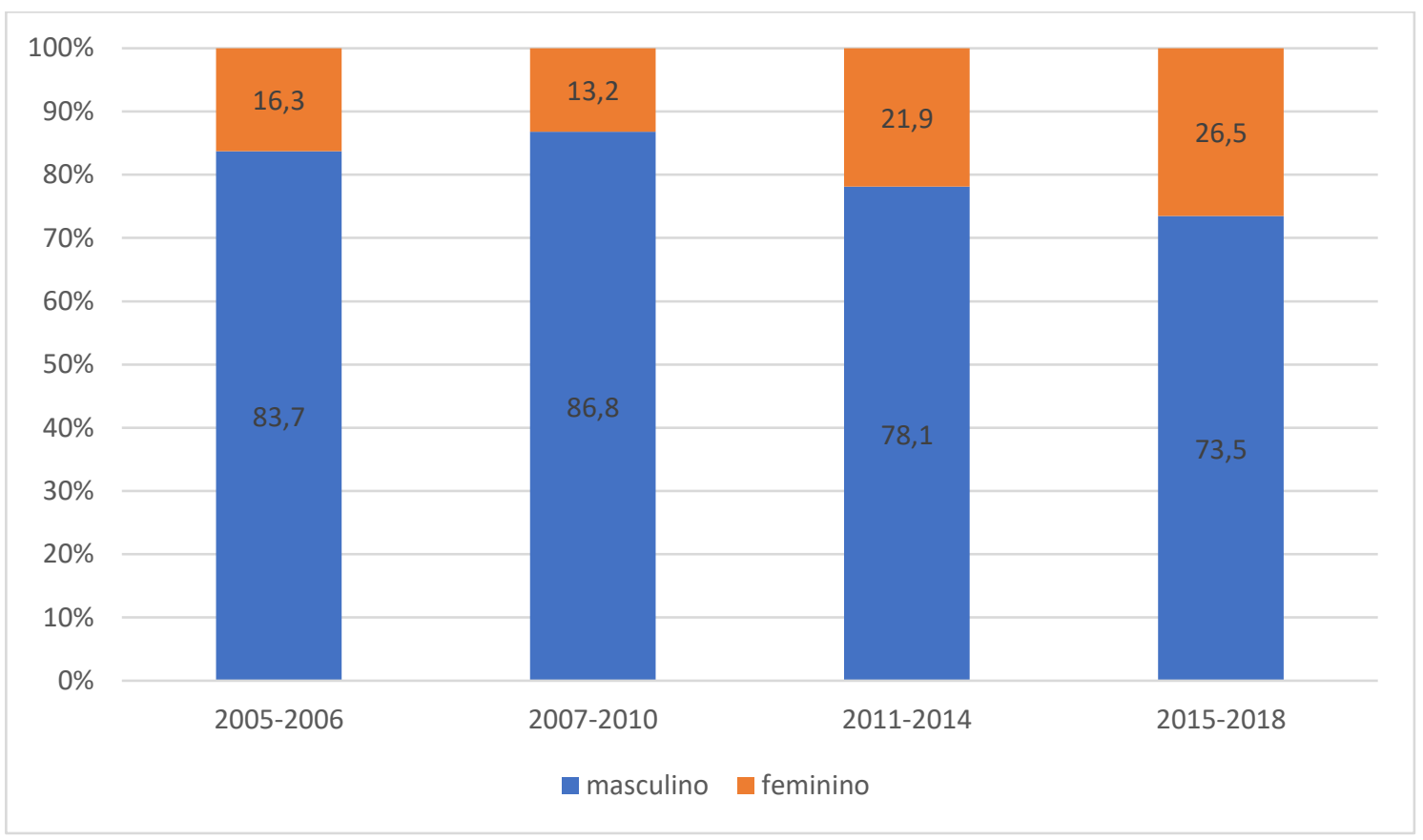

Fonte: Elaboração própria a partir dos dados dos Relatórios Anuais da Presidência do Senado

Outra característica é a composição a partir do gênero dos titulares. Como se pode notar no gráfico 4, fica clara a maioria masculina na comissão: sempre mais de $70 \%$ dos indicados para a CDH são homens. Todavia, nota-se um crescimento da participação de mulheres no período de 2011 a 2018, chegando a 26,5\% na última legislatura. Entretanto, observa-se também que no período de 2007-2010 houve um decréscimo na participação de mulheres: nesse período a indicação de mulheres para titulares da $\mathrm{CDH}$ atingiu seu patamar mais baixo $(13,2 \%)$. Sabemos que de modo geral, a representação feminina na política brasileira é muito pequena, e o Senado não é exceção. Comparado ao trabalho de Lemos e Renincheski (2008), citado anteriormente, que registraram uma participação ínfima das mulheres na Comissão de Constituição e Justiça na década de 1990, constatamos um aumento dessa participação, porém ainda está longe de se tornar igual à masculina. 
SOUZA E SILVA, Jonatas N. A. A comissão de direitos humanos e legislação participativa (CDH) no senado brasileiro: um estudo sobre sua composição (2005-2018). Caos - Revista Eletrônica de Ciências Sociais, João Pessoa, n. 23, p. 79 -112, jul./dez. 2019. Disponível em: https://periodicos.ufpb.br/ojs2/index.php/caos/index.

Dentro de um cenário social predominantemente machista, a participação das mulheres na política é pequena. Por exemplo, tendo dificuldades como a dupla jornada cuidar da casa, trabalho e educação dos filhos - as mulheres brasileiras "vivenciam conflitos para conciliar a vida pessoal com a profissional, pois ainda lhes cabe a responsabilidade de cuidados da prole, na tradicional divisão dos papéis" (BUSANELLO; REHBEIN, 2017, p. 113), o que ocasiona um forte incentivo para não participação em atividades políticas. Vale ressaltar também, que a CDH do Senado é uma comissão que não sofre influência da Lei $9.504 / 97,,^{5}$ visto que esta funciona com base na proporcionalidade, e as eleições do Senado são majoritárias, o que deixa o ingresso de mulheres no Senado mais difícil.

Todavia, mesmo com tais barreiras, a participação das mulheres na política vem aumentando. Como visto nos dados de 2011-2018, a participação feminina na comissão passa dos $20 \%$ mantendo uma taxa crescente de uma legislatura para outra, porém ainda não em nível de equidade. Cabe destacar que a comissão pode ser classificada como soft politics de acordo com a categorização feita por Busanello e Rehbein (2017), a respeito das comissões na Câmara dos Deputados. Tal categorização classifica as comissões entre hard, midle e soft politcs, destacando que as mulheres estão mais presentes nas lideranças das comissões (presidências e vice-presidências) com menor poder de impacto político e/ou que tange a atividades referentes ao gênero feminino. Ou seja, a representação feminina crescente na comissão pode estar associada a esta característica apontada na tipologia proposta pelas autoras.

Um último ponto a ser destacado sobre o gênero dentro da comissão, é que as mulheres, por mais sub-representadas, ocuparam a presidência da $\mathrm{CDH}$ por 3 vezes: Ana Rita (PT) em 2014, e Regina Souza (PT) em 2017 e 2018. Sendo que a senadora Ana Rita havia ocupado a vice-presidência da CDH de 2011 até 2013. Cabe destacar que as senadoras em questão são do Partido dos Trabalhadores (PT), o que condiz com o estudo

\footnotetext{
${ }^{5}$ Lei que determina a cota de $30 \%$ de mulheres na lista eleitoral referente à Câmara dos Deputados, Assembleia Legislativa, Assembleias Legislativas e Câmaras Municipais.
} 
SOUZA E SILVA, Jonatas N. A. A comissão de direitos humanos e legislação participativa (CDH) no senado brasileiro: um estudo sobre sua composição (2005-2018). Caos - Revista Eletrônica de Ciências Sociais, João Pessoa, n. 23, p. 79 -112, jul./dez. 2019. Disponível em: https://periodicos.ufpb.br/ojs2/index.php/caos/index.

de Busanello e Rehbein (2017), que indica que os partidos de esquerda detêm maiores quantidade de mulheres em cargos de presidência e vice-presidência nas comissões da Câmara dos Deputados, o mesmo se verificando no Senado.

Gráfico 5 - Número de mandatos no Senado dos ocupantes de vaga de titular na CDH

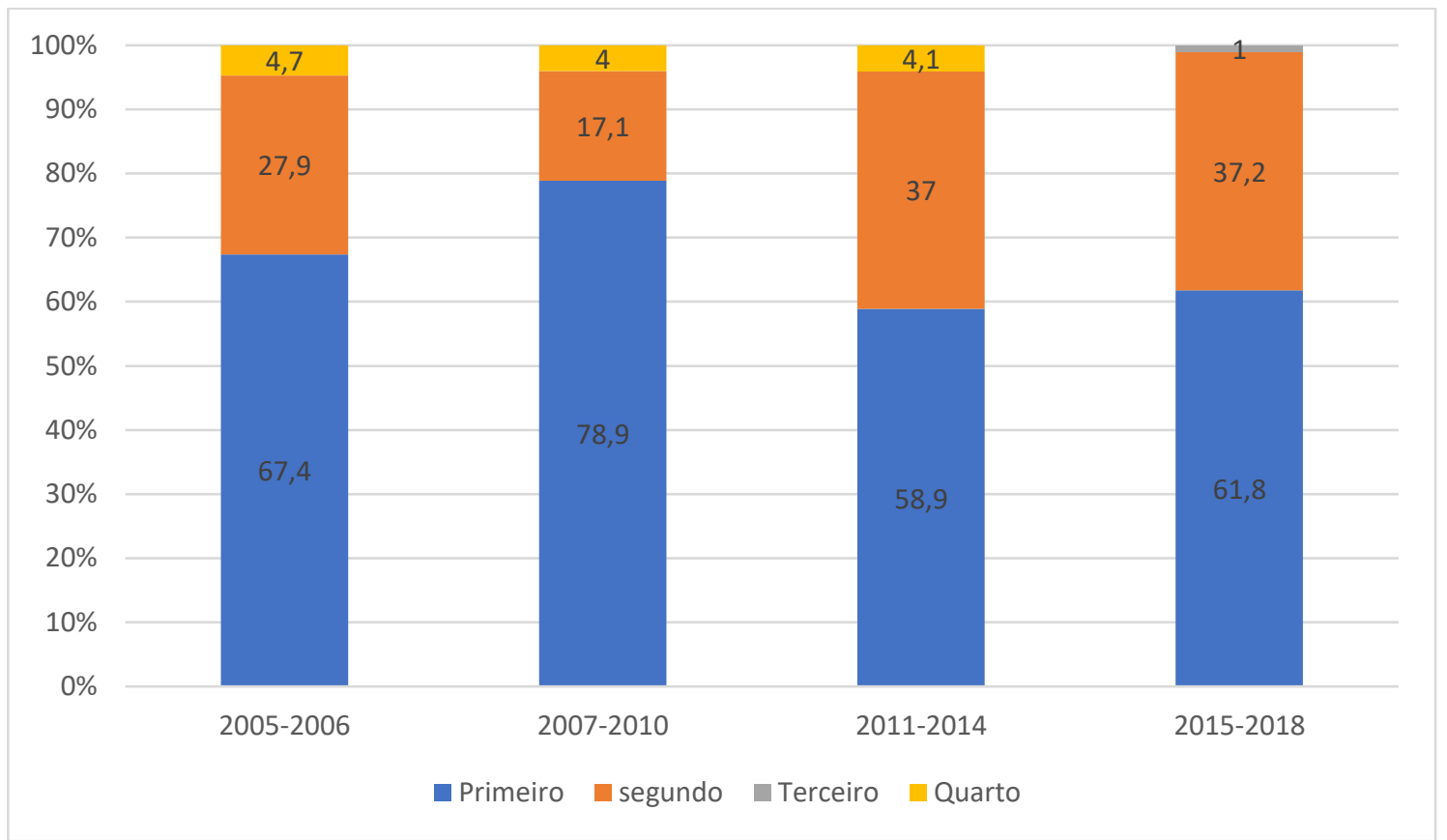

Fonte: Elaboração própria a partir dos dados dos Relatórios Anuais da Presidência do Senado

Outro elemento a se destacar sobre a composição dos membros da CDH é o número de mandatos no Senado dos titulares da comissão. A maioria dos senadores exerce primeiro mandato, seguida por aqueles em segundo mandato, com pequena taxa daqueles em quarto mandato, e apenas $1 \%$ no terceiro mandato (este último verificado em 2015-2018). Desta forma, observa-se que os senadores na CDH não estariam majoritariamente, entre os com maior experiência na casa. Todavia, ainda há um pequeno grupo de parlamentares “experientes” ocupando essa comissão. Além disso, como iremos mostrar mais adiante, o baixo número de mandatos exercidos não significa pouca experiência política: os senadores, muitas vezes, apresentam longa trajetória nos poderes Executivo e Legislativo nos diferentes níveis da federação. 
SOUZA E SILVA, Jonatas N. A. A comissão de direitos humanos e legislação participativa (CDH) no senado brasileiro: um estudo sobre sua composição (2005-2018). Caos - Revista Eletrônica de Ciências Sociais, João Pessoa, n. 23, p. 79 -112, jul./dez. 2019. Disponível em: https://periodicos.ufpb.br/ojs2/index.php/caos/index.

Gráfico 6 - Distribuição das vagas de titulares da CDH de acordo com o tipo de mandato exercido pelo Senador

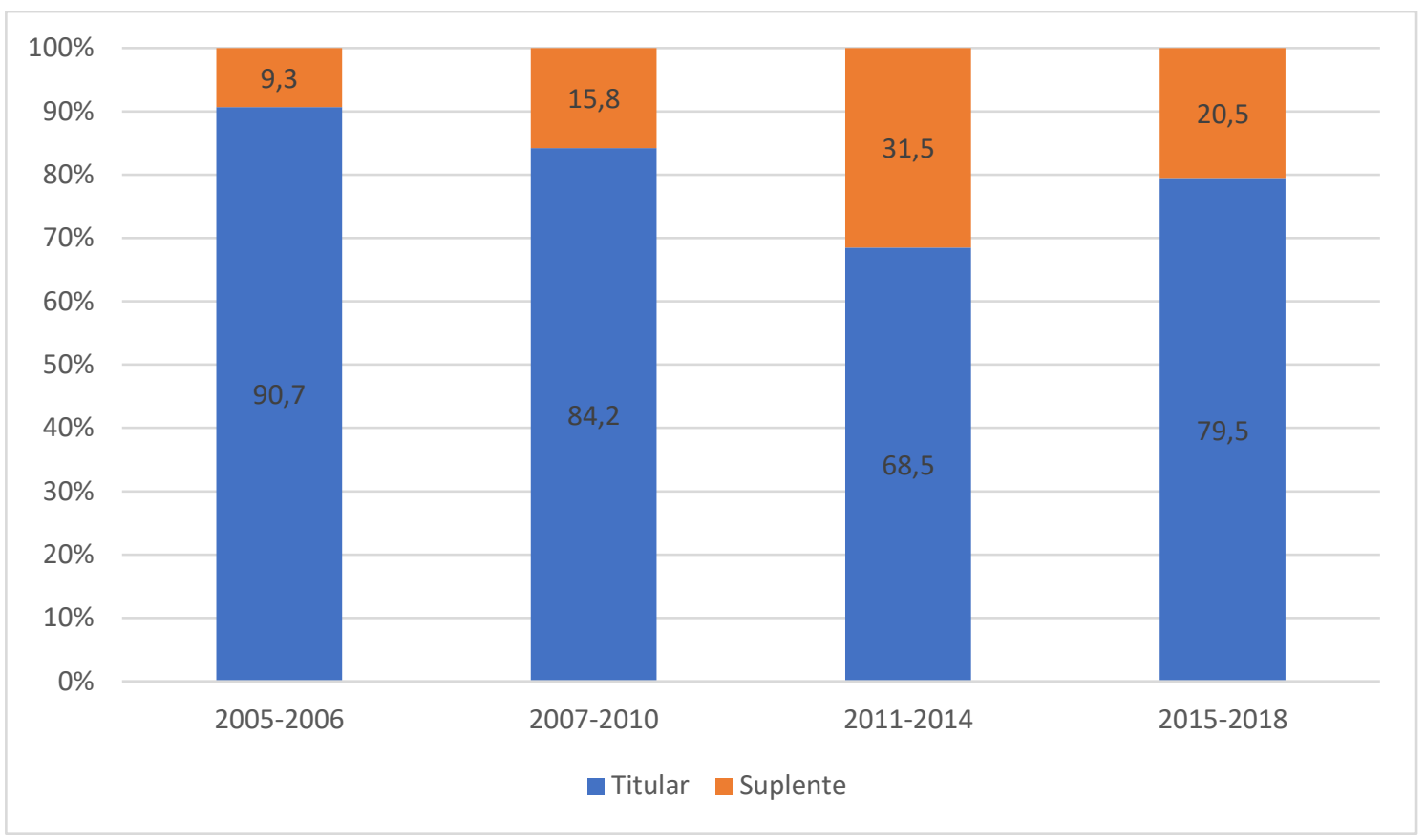

Fonte: Elaboração própria a partir dos dados dos Relatórios Anuais da Presidência do Senado

Outro ponto a se destacar é o tipo de mandato que os senadores exercem na Câmara Alta, isto é, se são titulares ou suplentes. Devido ao fato de muitos senadores ocuparem cargos nos governos federais, estaduais ou mesmo municipais, a presença de suplentes no Senado se mostra contínua, e desta forma, as comissões podem ser ocupadas também por senadores suplentes.

No que tange à titularidade dos senadores, é visto um crescimento da entrada de suplentes na comissão de 2005 a 2014, com o pico máximo de 2011-2014, com taxa de 31,5\%. Entre 2015-2018, essa taxa diminuiu em relação à legislatura anterior, alcançando o percentual de $20,5 \%$.

Um ponto a se destacar sobre a representação dos suplentes é que eles têm uma participação significante na comissão desde 2005 (pelo fato de tais senadores não terem necessidade de respaldo no eleitorado, eles podem ser estratégicos em votações acirradas). Tais atores podem representar interesses distintos no âmbito dos direitos humanos. Como apontado por Neiva e Izumi (2012), a maioria dos suplentes é composta 
SOUZA E SILVA, Jonatas N. A. A comissão de direitos humanos e legislação participativa (CDH) no senado brasileiro: um estudo sobre sua composição (2005-2018). Caos - Revista Eletrônica de Ciências Sociais, João Pessoa, n. 23, p. 79 -112, jul./dez. 2019. Disponível em: https://periodicos.ufpb.br/ojs2/index.php/caos/index.

por empresários, além disso, por serem "eleitos" sem nenhum voto direto (e tendo uma taxa de reeleição baixa), os senadores suplentes podem apenas representar demandas e interesses individuais, o que pode significar um perigo aos direitos humanos. ${ }^{6}$ Fato agravado pelo fato de que o cargo de suplência, como aponta a literatura, prescinde de experiência política e respaldo eleitoral. Desta forma, a atuação dos suplentesempresários pode ser negativa em relação aos direitos humanos, caso haja contradição com os interesses empresariais dos senadores.

Gráfico 7- Nível de escolaridade formal dos membros da CDH

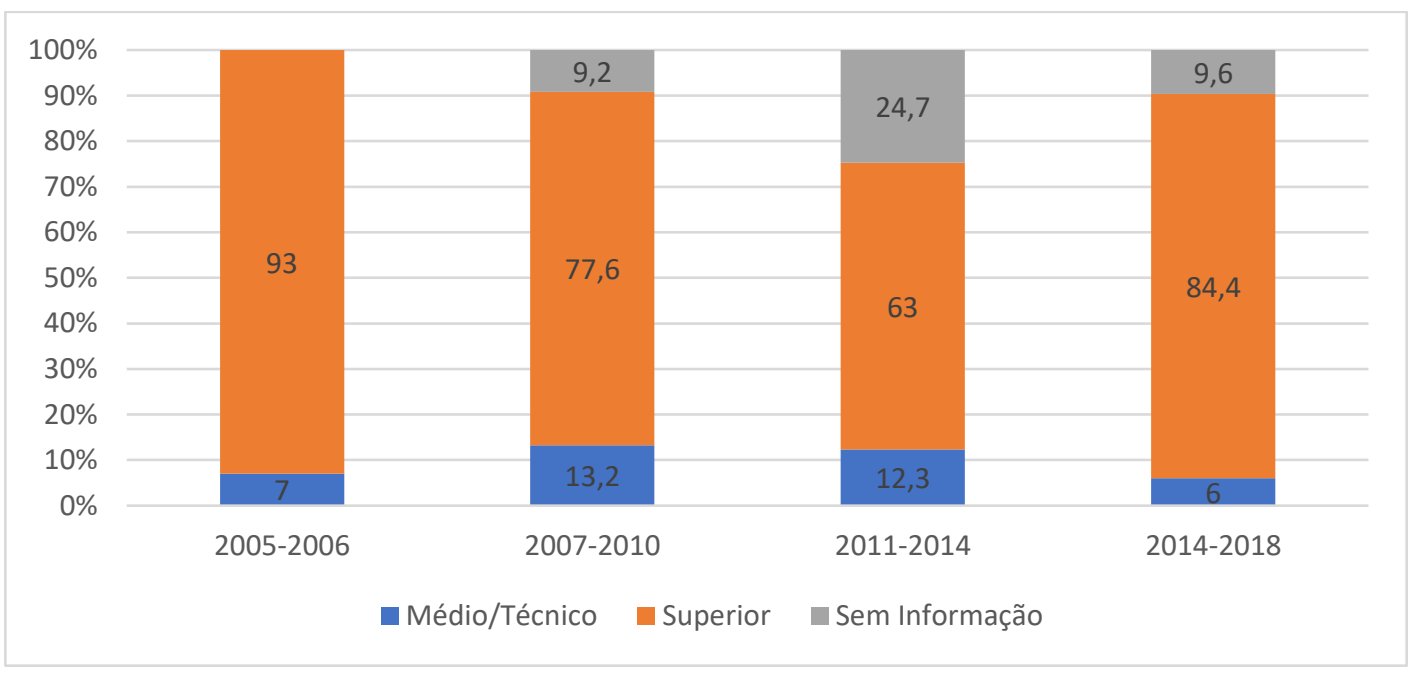

Fonte: Elaboração própria a partir dos dados dos Relatórios Anuais da Presidência do Senado

No quesito formação, é nítida a predominância do ensino superior, sendo poucos os que possuem apenas o nível médio/técnico. No período de 2011-2014, há um aumento na classe "sem informação", o que talvez seja um reflexo da maior taxa de suplentes na comissão: como informações são colocadas pelos próprios senadores no site do Senado Federal, muitas vezes esses parlamentares não colocam informações completas. Todavia, mesmo com essa incompletude de informações, em todas as legislaturas, os ocupantes dos cargos de titulares na CDH com título superior representam mais de 60\%. Em suma, a comissão apresenta alta escolaridade, o que condiz com pesquisas anteriores, como apontam Lemos e Renincheski (2008, p. 101-2): "o nível dos senadores tem-se mantido,

\footnotetext{
${ }^{6}$ Dentre as profissões declaradas, a maior taxa é a de empresários.
} 
SOUZA E SILVA, Jonatas N. A. A comissão de direitos humanos e legislação participativa (CDH) no senado brasileiro: um estudo sobre sua composição (2005-2018). Caos - Revista Eletrônica de Ciências Sociais, João Pessoa, n. 23, p. 79 -112, jul./dez. 2019. Disponível em: https://periodicos.ufpb.br/ojs2/index.php/caos/index.

ao longo da década de 90, na faixa do ensino superior, o que nos leva a considerar o Senado como mais elitista do que a Câmara, como de resto fato ele foi desenhado para ser". Sendo assim, no tocante à escolaridade, a CDH demonstra compatibilidade com estudos anteriores.

Tabela 2 - Profissões declaradas dos membros da CDH

\begin{tabular}{|c|c|}
\hline Profissões & Porcentagem \\
\hline Professor & 14,2 \\
\hline Advogado & 11,7 \\
\hline Empresário & 7,5 \\
\hline Engenheiro & 6,7 \\
\hline Jornalista & 6,7 \\
\hline Médico & 5 \\
\hline Administrador & 4,2 \\
\hline Economista & 4,2 \\
\hline Político & 4,2 \\
\hline Servidor público & 3,3 \\
\hline Agropecuarista & 2,5 \\
\hline Bancário & 2,5 \\
\hline Pedagoga & 1,7 \\
\hline Técnico em contabilidade & 1,7 \\
\hline Agricultor & 0,8 \\
\hline Arquiteto & 0,8 \\
\hline Delegado & 0,8 \\
\hline Engenheiro Agrônomo & 0,8 \\
\hline Geógrafo & 0,8 \\
\hline Metalúrgico & 0,8 \\
\hline Pastor Evangélico & 0,8 \\
\hline Promotor & 0,8 \\
\hline Psicóloga & 0,8 \\
\hline Sociólogo & 0,8 \\
\hline Zootecnista & 0,8 \\
\hline Sem Informação & 15 \\
\hline
\end{tabular}

Fonte: Elaboração própria a partir dos dados dos Relatórios Anuais da Presidência do Senado ${ }^{7}$

No tocante à experiência prévia dos senadores, é visto que em 2005-2006 há a predominância da experiência dos membros tanto no Executivo quanto no Legislativo, isto é, o mesmo parlamentar já tinha ocupado anteriormente cargos nesses dois ramos do Estado, esse fato podendo estar relacionado ao caráter de novidade da comissão, criada

\footnotetext{
7 Nas análises apresentadas anteriormente, focamos nas entradas dos parlamentares na CDH, ano a ano (totalizando 274 entradas), neste gráfico, optamos por abordar as profissões por parlamentar (no período, 90 parlamentares ocuparam a comissão), sendo que cada um chegou a indicar até três profissões, as quais optamos por computá-las integralmente.
} 
SOUZA E SILVA, Jonatas N. A. A comissão de direitos humanos e legislação participativa (CDH) no senado brasileiro: um estudo sobre sua composição (2005-2018). Caos - Revista Eletrônica de Ciências Sociais, João Pessoa, n. 23, p. 79 -112, jul./dez. 2019. Disponível em: https://periodicos.ufpb.br/ojs2/index.php/caos/index.

em 2005, o que pode ter ocasionado interesse dos parlamentares, visto que ainda era desconhecido o seu potencial.

No tocante às profissões, é evidente a maior frequência de professores ${ }^{8}$ seguidos por advogados, empresários e engenheiros. Dentro da $\mathrm{CDH}$, a pluralidade de profissões é significativa, valendo ressaltar que a conceituação de profissão para a área de direitos humanos, não possui delimitação clara, haja vista a sua ampla abrangência de atuação, permitindo o enquadramento das mais diversas profissões. Importante destacar a relativa taxa de professores, visto que a composição da comissão é delimitada pelo colégio dos líderes, e como aponta Santos (2002, p. 251), "expertise prévia sobre políticas específicas é uma variável decisiva nos cálculos dos legisladores na hora de fazer indicações para as comissões", ou seja, a comissão é composta por membros que têm atuação profissional enquadrada na temática da comissão.

Gráfico 8 - Experiência Prévia dos Senadores em cargos eletivos (porcentagem)

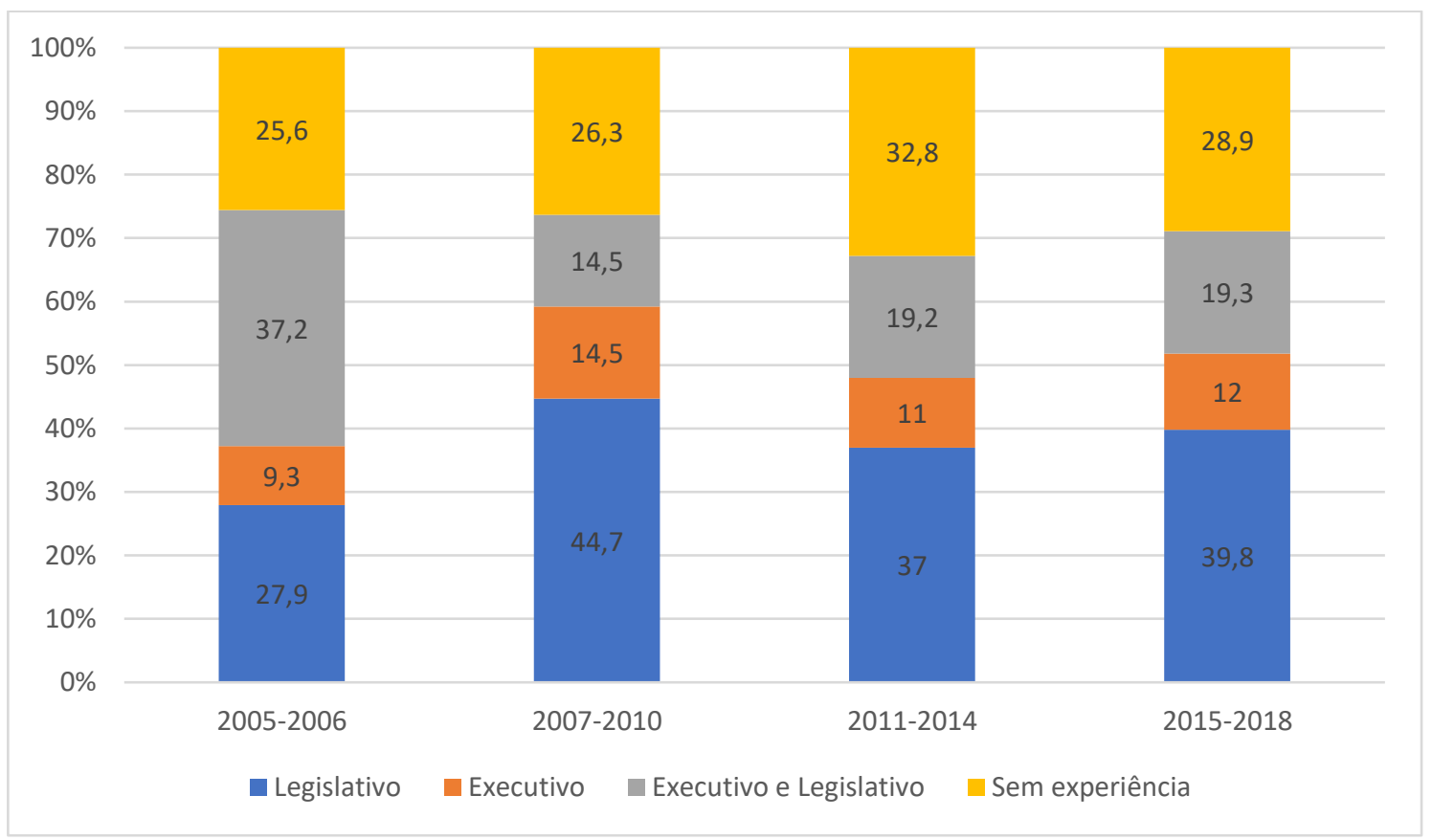

Fonte: Elaboração própria a partir dos dados dos Relatórios Anuais da Presidência do Senado

\footnotetext{
${ }^{8}$ A maior frequência (15\%) está como os "Sem Informação" (SI), correspondendo àqueles que não registraram a profissão em suas biografias no site do Senado Federal. Logo em seguida vêm os professores com $14,2 \%$.
} 
SOUZA E SILVA, Jonatas N. A. A comissão de direitos humanos e legislação participativa (CDH) no senado brasileiro: um estudo sobre sua composição (2005-2018). Caos - Revista Eletrônica de Ciências Sociais, João Pessoa, n. 23, p. 79 -112, jul./dez. 2019. Disponível em: https://periodicos.ufpb.br/ojs2/index.php/caos/index.

A continuidade dos dados mostra que é notável a experiência em cargos no Legislativo, o que corresponde às conclusões de Lemos e Renincheski (2008), ao demonstrarem que a maior experiência prévia dentro da $\mathrm{CCJ}$ é formada por aqueles que já ocuparam cargos eletivos no Legislativo. Um último ponto a destacar é a categoria "sem experiência" que apresenta grau significativo em todas as 4 legislaturas analisadas, isso se deve à entrada de suplentes (56,9\% das entradas que não possuíam experiência em cargos eletivos eram suplentes). Cabe também notar que aqui se trata apenas dos cargos eletivos, podendo os senadores terem ocupado outros cargos no Estado (secretários de governo nas três esferas, assessores parlamentares, chefias em autarquias etc.), o que pode não refletir "inexperiência" no trato da coisa pública.

Gráfico 9 - Número de anos como membros titulares na CDH

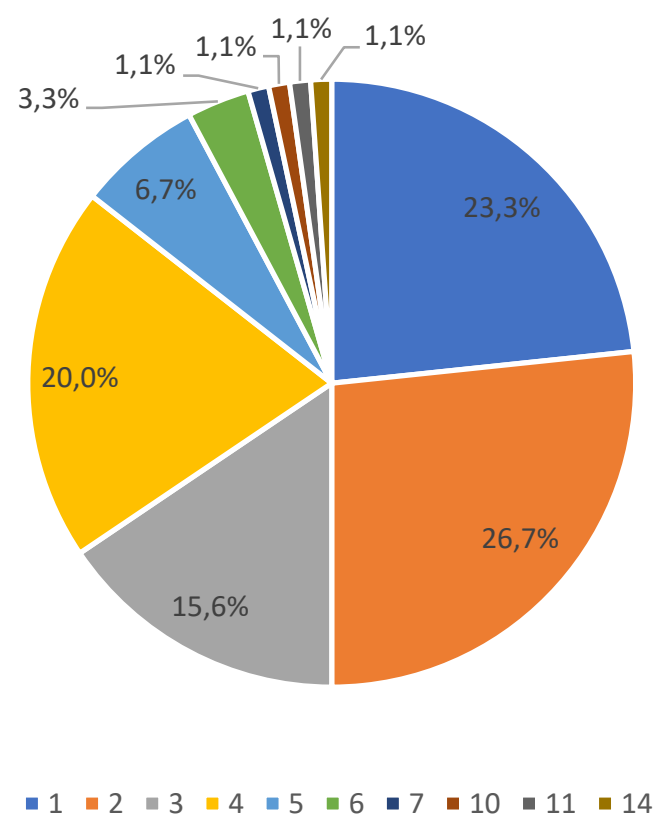

Fonte: Elaboração própria a partir dos dados dos Relatórios Anuais da Presidência do Senado

No que tange à permanência na $\mathrm{CDH}, 86 \%$ da composição não chega a passar de 4 anos (2 mandatos completos de titular), sendo importante ressaltar que somente 3 senadores completaram um mandato completo do Senado ( 8 anos) na referida comissão: 
SOUZA E SILVA, Jonatas N. A. A comissão de direitos humanos e legislação participativa (CDH) no senado brasileiro: um estudo sobre sua composição (2005-2018). Caos - Revista Eletrônica de Ciências Sociais, João Pessoa, n. 23, p. 79 -112, jul./dez. 2019. Disponível em: https://periodicos.ufpb.br/ojs2/index.php/caos/index.

Cristovam Buarque (10 anos), Magno Malta (11 anos) e Paulo Paim (14 anos). O senador Paulo Paim se manteve na comissão desde o ano da sua criação, em 2005, até 2018, caracterizando uma possível teoria informacional, visto que fica claro o interesse do senador pela temática da comissão, o mesmo argumento pode ser utilizado para aqueles com mais de 10 anos de permanência na comissão.

Todavia, retirando essas exceções, a maioria da comissão não condiz com o exposto pela teoria informacional, visto que metade da comissão nem chega a 2 anos (1 mandato), sendo a média de permanência de 3,03 anos. O que demonstra que dentro da CDH não há um caráter de gerar expertise para a maioria dos seus membros, com ressalva aos senadores citados. Isso pode estar ligado ao fato de o Colégio dos Líderes delimitar aqueles que ingressaram na comissão, inclusive podendo trocar seus membros antes do final dos mandatos. Sendo assim, no quesito da permanência, vemos aspectos de uma teoria informacional e fatores que a enfraquecem ao mesmo tempo. É notório que a grande parte da comissão não busca adquirir expertise por tempo de permanência.

Dessa forma, aspectos das teorias partidária e distributiva podem trazer elementos que esclareçam o papel da CDH, ou seja, "o principal ponto a ser destacado é que cada uma destas teorias, isoladamente, concebem um cenário legislativo que não pode capturar de maneira adequada a complexa rede de perspectivas e motivações sob as quais as nossas comissões estão assentadas" (NASCIMENTO, 2012, p.62). Sendo assim, não há como categorizar uma comissão de uma forma única dentro das teorias positivas estadunidenses, porém há como identificar casos que se expliquem por elas ou com adaptações delas para a realidade brasileira. 
SOUZA E SILVA, Jonatas N. A. A comissão de direitos humanos e legislação participativa (CDH) no senado brasileiro: um estudo sobre sua composição (2005-2018). Caos - Revista Eletrônica de Ciências Sociais, João Pessoa, n. 23, p. 79 -112, jul./dez. 2019. Disponível em: https://periodicos.ufpb.br/ojs2/index.php/caos/index.

Gráfico 10 - Partidos dos Presidentes da CDH

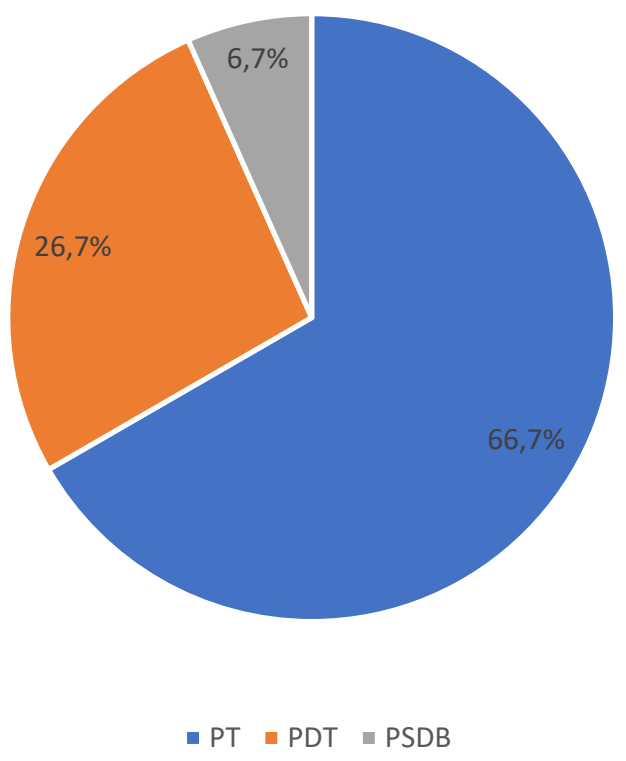

Fonte: Elaboração própria a partir dos dados dos Relatórios Anuais da Presidência do Senado

Sobre a presidência da comissão, é perceptível a predominância do partido do chefe do Executivo (PT), seguido pelo PDT que a ocupou por duas vezes (2005-2006). ${ }^{9}$ Quanto ao PSDB, ele ocupou a presidência da CDH por menos de um ano, em 2005, sendo somente essa a sua participação na presidência no período estudado, indicando que o principal partido de oposição atuou na presidência da $\mathrm{CDH}$ apenas no primeiro ano de sua existência e não chegou a durar nem um ano.

É nítida a predominância do partido do chefe Executivo, assim como da sua coalizão, havendo uma participação ínfima da oposição (aqui considerado o PSDB, pois o PDT se encaixa no espectro ideológico do PT). Tal fato é pertinente, visto que os poderes do presidente da comissão são de relevante importância. Como aponta Aguiar (2013), o presidente tem poder de agenda, poder de definir as matérias que serão deliberadas no colegiado da comissão, poder de veto previsto no Regime Interno, permitindo-lhe discricionariedade de pautar os projetos, assim como delimitar as

\footnotetext{
${ }^{9}$ O PDT passa a compor a coalizão de governo a partir de 2007, ou seja, ocupou a presidência antes de fazer parte da coalizão de governo.
} 
SOUZA E SILVA, Jonatas N. A. A comissão de direitos humanos e legislação participativa (CDH) no senado brasileiro: um estudo sobre sua composição (2005-2018). Caos - Revista Eletrônica de Ciências Sociais, João Pessoa, n. 23, p. 79 -112, jul./dez. 2019. Disponível em: https://periodicos.ufpb.br/ojs2/index.php/caos/index.

relatorias dos projetos. Em suam, o presidente da comissão usufrui de extenso arcabouço institucional que lhe confere influência sobre os projetos, tanto de forma positiva como negativa.

Vale destacar que nos 14 anos de funcionamento da comissão, em somente três, as mulheres obtiveram o cargo da presidência, conforme citado anteriormente, embora tenha havido, em todo o período estudado, a participação feminina. Este fato parece destacar aquilo que Busanello e Rehbein (2017) chamaram o fenômeno do "teto de vidro", referindo-se às barreiras invisíveis que as mulheres precisam superar para alcançar cargos de poder dentro do Legislativo. Vale lembrar que as duas senadoras (Ana Rita e Regina Souza), antes de assumirem a presidência, tiveram experiência prévia na comissão.

Gráfico 11 - Experiência Prévia na CDH dos presidentes da comissão

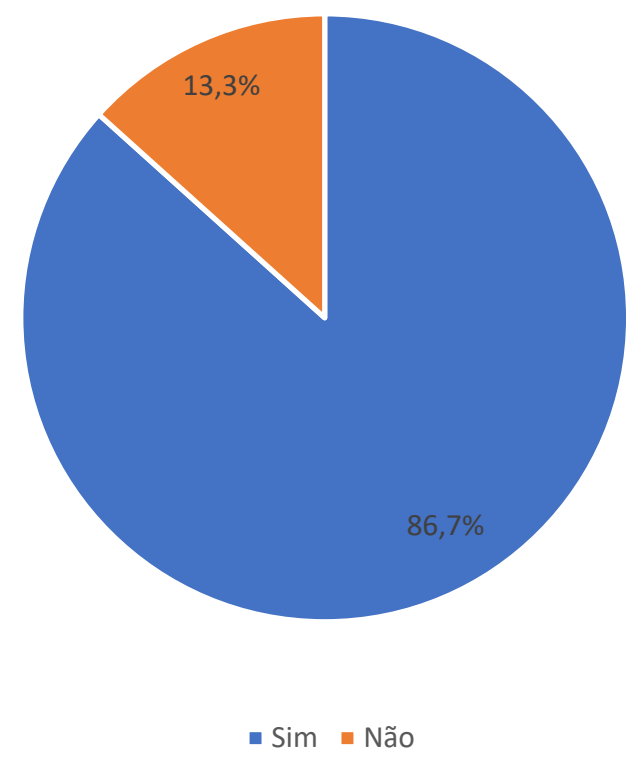

Fonte: Elaboração própria a partir dos dados dos Relatórios Anuais da Presidência do Senado

Pelo fato de a presidência da comissão ser um cargo de relevância, é esperado que este espaço seja ocupado por senador que tenha alto grau de experiência prévia na mesma, não havendo espaço para iniciantes. No gráfico 11, os 13,3\% "sem experiência" representam os dois primeiros presidentes da comissão no ano de 2005 (ano de criação 
SOUZA E SILVA, Jonatas N. A. A comissão de direitos humanos e legislação participativa (CDH) no senado brasileiro: um estudo sobre sua composição (2005-2018). Caos - Revista Eletrônica de Ciências Sociais, João Pessoa, n. 23, p. 79 -112, jul./dez. 2019. Disponível em: https://periodicos.ufpb.br/ojs2/index.php/caos/index.

da comissão, o que, por conseguinte, os caracteriza como sem experiência, uma vez que a comissão não existia), os demais senadores já haviam passado pela comissão antes de assumir a presidência. Dessa forma, parece ser critério para assumir o cargo ter experiência prévia na comissão, configurando um caráter de necessidade de expertise prévia.

Além disso, nos 14 anos de seu funcionamento, a CHD foi presidida por 5 senadores: Cristovam Buarque, Juvêncio Fonseca, Paulo Paim, Ana Rita e Regina Souza, sendo a presença do PT a mais significativa. Paulo Paim ocupou a presidência por 7 vezes. Cristovam Buarque, do PDT, ocupou o cargo por 4 vezes. Este dados corroboram a regra de seniority.

Gráfico 12 - Partidos dos vice-presidentes da CDH

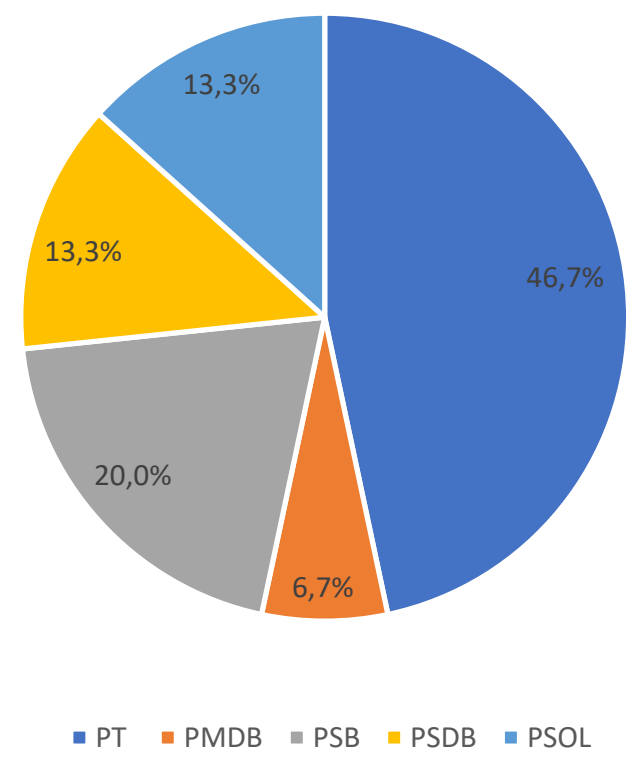

Fonte: Elaboração própria a partir dos dados dos Relatórios Anuais da Presidência do Senado

No tocante aos vice-presidentes, a diversidade partidária é maior, 5 partidos. Destacamos que o PSB obteve 3 vezes o posto no período de 2014-2016, sendo que esteve na coalizão de 2006-2010, ou seja, ocupou o posto enquanto esteve fora da coalizão. O PMDB, como base do governo de 2005-2015, ocupou somente uma vez a vicepresidência, e nenhuma vez a presidência, o que pode demonstrar o desinteresse do 
SOUZA E SILVA, Jonatas N. A. A comissão de direitos humanos e legislação participativa (CDH) no senado brasileiro: um estudo sobre sua composição (2005-2018). Caos - Revista Eletrônica de Ciências Sociais, João Pessoa, n. 23, p. 79 -112, jul./dez. 2019. Disponível em: https://periodicos.ufpb.br/ojs2/index.php/caos/index.

partido nas atividades de mando, visto que sua presença é notável em toda a composição da $\mathrm{CDH}$.

Referente ao PSOL, este esteve na comissão de 2007 a 2015, tendo como vicepresidente o senador José Nery, sendo importante destacar que ele foi membro titular da comissão por dois anos antes de assumir o cargo (titular em 2007-2008, vice-presidente 2009-2010), reforçando o argumento de experiência prévia. O PSDB, como oposição, teve sua representação na vice-presidência ao mesmo tempo em que a presidência foi ocupada por um senador do PT, fato interessante de se notar. Em suma, o partido do governo ocupou a vice-presidência de forma expressiva, porém deixando espaço para oposição (PSDB) e o PSOL (espectro ideológico semelhante) representarem a sua proporcionalidade dentro da comissão.

Gráfico 13 - Experiência Prévia dos vice-presidentes da CDH na comissão

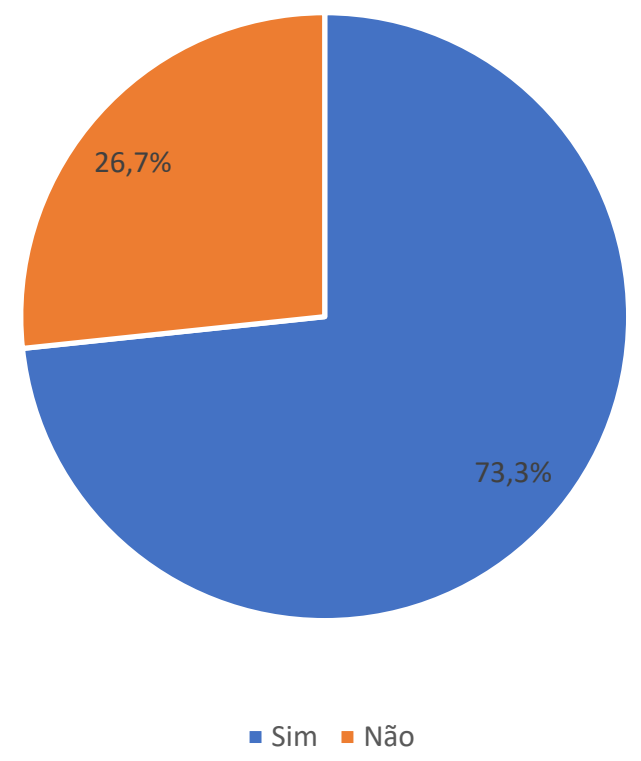

Fonte: Elaboração própria a partir dos dados dos Relatórios Anuais da Presidência do Senado

Sobre a experiência prévia dos senadores na comissão antes de ocupar o cargo de vice-presidente, vemos que maioria a ocupar o cargo teve passagem anterior na $\mathrm{CDH}$. Todavia, em comparação ao cargo de presidente, a vice-presidência não é tão criteriosa. 
SOUZA E SILVA, Jonatas N. A. A comissão de direitos humanos e legislação participativa (CDH) no senado brasileiro: um estudo sobre sua composição (2005-2018). Caos - Revista Eletrônica de Ciências Sociais, João Pessoa, n. 23, p. 79 -112, jul./dez. 2019. Disponível em: https://periodicos.ufpb.br/ojs2/index.php/caos/index.

Porém, esse fato não categoriza a vice-presidência como cargo de menor importância. Apesar de regimentalmente ela não possuir atribuições próprias - o RISF destaca apenas as atribuições do presidente -, ao olharmos os dados, vemos que Paulo Paim, Ana Rita e José Nery ocuparam o cargo de vice antes da presidência, indicando a vice-presidência como cargo de ascensão.

Posteriormente, o senador Paulo Paim (PT), nos anos de 2017-2018, voltou ao cargo de vice-presidente da $\mathrm{CDH}$, durante o governo Temer, talvez como resultado de algum acordo, considerando-se que o senador passou a ocupar o cargo após o impeachment da presidenta Dilma, também do PT. ${ }^{10} \mathrm{O}$ fato do senador estar presente na comissão, mesmo após a saída do seu partido do poder, adere a pressupostos da teoria informacional, pois acabou prevalecendo o critério de senority juntamente com expertise, o que o torna relevante dentro da comissão.

\section{Considerações Finais}

Visto que as comissões permanentes no cenário pós-88, se tornam espaços chaves para o processo centralizador de decisões, uma vez que as regras internas delimitam a primazia em sua deliberação sobre os temas os quais lhe são de competência, elas viraram espaço de interesse para os senadores, uma vez que estes necessitam de retorno eleitoral, e as comissões são lócus privilegiado de ações e visibilidade política. A organização dos trabalhos legislativos se encontra no âmbito das comissões, tanto nas perspectivas informacional, partidária e distributivista. Dessa forma, a Comissão de Direitos Humanos e Legislação Participativa é ambiente para aqueles que representam a temática da comissão, tanto de forma positiva como negativa, relacionada aos Direitos Humano, fatos que podem ser observados na quantidade diversificada de profissões e partidos presentes na sua composição.

\footnotetext{
${ }^{10}$ Cabe notar que o Senador Paulo Paim, atualmente (2019), ocupa novamente a presidência da CDH.
} 
SOUZA E SILVA, Jonatas N. A. A comissão de direitos humanos e legislação participativa (CDH) no senado brasileiro: um estudo sobre sua composição (2005-2018). Caos - Revista Eletrônica de Ciências Sociais, João Pessoa, n. 23, p. 79 -112, jul./dez. 2019. Disponível em: https://periodicos.ufpb.br/ojs2/index.php/caos/index.

Dentro desse contexto, torna-se necessário verificar o perfil dos senadores que compõem as comissões e o que a bibliografia destaca sobre o assunto. $\mathrm{Na}$ Comissão de Direitos Humanos e Legislação Participativa do Senado brasileiro (CDH), vemos uma composição partidária com crescente fragmentação, respeitando a proporcionalidade entre o plenário e a comissão. Em termos regionais há uma predominância das áreas Norte e Nordeste dentro da comissão, o que pode representar o interesse de regiões com baixo Índice de Desenvolvimento Humano (IDH) em busca de políticas temáticas regionais. Em relação a idades, a legislatura em que a CDH foi criada (2005-2006) apresenta a maior frequência de membros com mais de 70 anos; após predominância em 2 legislaturas (2007-2014) das frequências de 50-59 anos, e na última (2015-2018), leve maioria daqueles com 60-69 anos, não deixando claro um critério de idade.

No que tange à questão de gênero, vemos ainda a predominância do sexo masculino. Todavia, com uma participação maior do sexo feminino se comparado a CCJ da década de 90 (LEMOS; RENINCHESKI, 2008). Ressaltamos que a participação de mulheres no Senado não é afetada pela lei de cotas de gênero devido ao sistema eleitoral majoritário, mesmo assim elas têm apresentado, na comissão, crescente participação, porém ainda longe de equidade. Destacamos ainda, o estudo de Busanello e Rehbein (2017) sobre a dificuldade do ingresso das mulheres na política no âmbito da Câmara dos Deputados, sendo o ingresso na Câmara Alta, ainda mais custoso. Porém, mesmo diante de tais barreiras, na $\mathrm{CDH}$, a representação feminina veio crescendo.

Referente aos mandatos dos senadores que estão na comissão, é importante destacar a duração de seus mandatos (8 anos, duas legislaturas), além disso, vale notar a incongruência, que torna o processo para ingresso no Senado mais seletivo, ocasionando a presença de senadores com carreiras políticas avançadas e de maior idade. Formalmente, o Senado se configura como uma Casa de "Anciões". Dentro desse contexto, a CDH apresenta dados referentes à idade que não apresentam padrões contínuos - crescentes, decrescentes ou estáveis - ao longo de todo o período estudado (2005-2018), e relacionando à idade com o número de mandatos, é notável a presença de senadores de 
SOUZA E SILVA, Jonatas N. A. A comissão de direitos humanos e legislação participativa (CDH) no senado brasileiro: um estudo sobre sua composição (2005-2018). Caos - Revista Eletrônica de Ciências Sociais, João Pessoa, n. 23, p. 79 -112, jul./dez. 2019. Disponível em: https://periodicos.ufpb.br/ojs2/index.php/caos/index.

primeiro e segundo mandato com idades diferentes, ou seja, aqueles que ingressam na CDH podem estar ocupando essa comissão por não terem seniority suficiente na Câmara Alta para ocupar as comissões mais desejadas, visto que a permanência daqueles com mais de 10 anos na comissão, restringe-se a 3 senadores (Paulo Paim, Cristovam Buarque, Magno Malta), e sendo que 50\% dos seus membros permaneceram na comissão por tempo máximo de até dois anos.

Talvez esse fato esteja relacionado ao poder que exerce a comissão. Busanello e Rehbein (2017) apresentam classificação sobre as comissões da Câmara dos Deputados de acordo com o poder e atuação que possuem, dividida em hard, midle e soft politcs. Segundo as autoras, a Comissão de Direitos Humano e Minoritários (CDHM) daquela casa, encontra-se na categoria soft politcs, tal atribuição pode ser aplicada à CDH do Senado. Contudo, a permanência de senadores por longos períodos na comissão, ainda que minoria, é um fato registrado.

Referente à titularidade e suplência daqueles que ingressam na comissão, foi vista significativa taxa de titulares, assim como uma participação crescente dos suplentes atingindo uma terça parte dos membros entre 2011-2014, fato preocupante uma vez que, segundo Neiva e Izumi (2012), os suplentes são atores que não atendem ao eleitorado, pois são eleitos sem voto direto, e em sua maioria são empresários com uma taxa maior de atuação com o Executivo em relação aos próprios titulares. Dessa forma, podem representar interesses individuais.

Retratando a escolaridade, vemos grande expressão de senadores com ensino superior, condizendo com a literatura sobre as comissões do senado brasileiro. A escolaridade elevada representa uma característica da composição do Senado, assim como experiência prévia em cargos eletivos. Há maior frequência de senadores com experiência somente em cargos Legislativos eletivos, com exceção para o ano de criação da comissão, quando aparecem parlamentares com passagens em cargos executivos e legislativos eletivos. 
SOUZA E SILVA, Jonatas N. A. A comissão de direitos humanos e legislação participativa (CDH) no senado brasileiro: um estudo sobre sua composição (2005-2018). Caos - Revista Eletrônica de Ciências Sociais, João Pessoa, n. 23, p. 79 -112, jul./dez. 2019. Disponível em: https://periodicos.ufpb.br/ojs2/index.php/caos/index.

Sobre as profissões, há presença significativa de professores, advogados e empresários. Destaca-se a difícil delimitação de profissões diretamente ligadas a direitos humanos, e atribui-se as escolhas aos líderes partidários, que são responsáveis pela indicação dos membros de acordo com a sua proporcionalidade para a composição das comissões, lembrando que as escolhas podem ser feitas pelo critério de expertise prévia, como aponta Santos (2002), respeitando a atuação profissional dos senadores, levando-os a comissões nas quais suas profissões tenham impacto no trabalho da comissão.

Sobre os presidentes e vice-presidentes da $\mathrm{CDH}$, é importante destacar que a preferência do partido do governo pela cadeira de presidente é nítida, uma vez que esta foi majoritariamente ocupada por ele (67\%). Nota-se também, que o partido do governo mostra significativa participação (47\%) também na ocupação da vice-presidência, o que demonstra o interesse do partido (PT) pela comissão.

Dessa forma, o perfil médio de um senador da CDH do Senado é um parlamentar com mais de 50 anos, com ensino superior, professor, advogado ou empresário, com experiência em cargos eletivos do Legislativo, sendo do Norte ou Nordeste, homem, no primeiro ou segundo mandato como senador. E em relação aos cargos de presidente na comissão, o perfil seria de um senador com média de 63,1 anos, da base do governo ou com espectro ideológico semelhante (PDT), com ressalva a única participação do PSDB em 2005. Sobre a vice-presidência, a média é de 57,2 anos de idade, havendo maior participação de outros partidos, se comparada à presidência.

\section{Referências}

AGUIAR, O. O. Os atores-chave no processo decisório no âmbito das comissões permanentes. E-legis, Brasília, n. 12, p. 137-152, set./dez. 2013. Disponível em: http://elegis.camara.leg.br/cefor/index.php/e-legis/article/view/148. Acesso em: 18/12/2019.

AMARAL, Ana Regina Villar Peres. O parlamento brasileiro: processo, produção e organização legislativa: o papel das comissões em perspectiva comparada. In: NICOLAU, Jairo; BRAGA, Ricardo de João. Para além das urnas: reflexões sobre a câmara dos deputados. Brasília: Centro de documentação e Informação/Edições Câmara, 2011, p. 149-177. 
SOUZA E SILVA, Jonatas N. A. A comissão de direitos humanos e legislação participativa (CDH) no senado brasileiro: um estudo sobre sua composição (2005-2018). Caos - Revista Eletrônica de Ciências Sociais, João Pessoa, n. 23, p. 79 -112, jul./dez. 2019. Disponível em: https://periodicos.ufpb.br/ojs2/index.php/caos/index.

ARAÚJO, P, M. O bicameralismo no Brasil: argumentos sobre a importância do senado na análise do processo decisório federal. Política \& Sociedade. Florianópolis: UFSC, v.11, n.21, p. 83-135, 2012. Disponível em: https://periodicos.ufsc.br/index.php/ politica/article/view/29036/24594. Acesso em: 18/12/2019.

BRASIL. Senado Federal. Regimento Interno: Resolução n. 93, de 1970. Brasília: Senado Federal, 2019. Disponível em: https://www25.senado.leg.br/documents/124 27/45868/RISF+2018+Volume+1.pdf/cd5769c8-46c5-4c8a-9af7-99be436b89c4. Acesso em: $16 / 12 / 2019$.

BUSANELLO, E.; REHBEIN, M. As deputadas federais na presidência e vicepresidência das comissões permanentes da câmara dos deputados: quem são elas e como chegaram lá? E-legis, Brasília, v. 10, n. 23, p. 106-132, 2017. Disponível em: http://elegis.camara.leg.br/cefor/index.php/e-legis/article/view/307. Acesso em: 18/12/2019.

FREITAS, Andréia. O presidencialismo da coalizão. Rio de Janeiro: Fundação Konrad Adenauer, 2016.

LEMOS, L. B.; RANINCHESKI, S. Carreiras políticas no senado brasileiro: um estudo das composições do plenário e da Comissão de Justiça e Cidadania na década de 1990. In: LEMOS, L. B. (Org.). O senado federal brasileiro no pós-constituinte. Brasília: Senado Federal; Unilegis, 2008, p. 87-120. Disponível em: https://www2. senado.leg.br/bdsf/bitstream/handle/id/180410/O\%20Senado\%20Federal\%20brasileiro $\% 20 \mathrm{no} \% 20 \mathrm{p} \% \mathrm{C} 3 \% \mathrm{~B} 3 \mathrm{~s}-\mathrm{constituinte} . \mathrm{pdf}$ ?sequence=1\&isAllowed=y. Acesso em: $18 / 12 / 2019$.

LIMONGI, Fernando; FIGUEIREDO, Argelina. Bases institucionais do presidencialismo de coalizão. Lua Nova, São Paulo, n. 44, p. 81-106, 1998. Disponível em: http://www.scielo.br/scielo.php?script=sci_arttext\&pid=S0102-64451998000200005\&1 ng=en\&nrm=iso. Acesso em: 18/12/2019.

MULLER, G. Comissões e partidos na câmara dos deputados: um estudo sobre padrões partidários de recrutamento para as comissões permanentes. Dados, Rio de Janeiro, v. 48, n.1, p. 371-394, jun. 2005. Disponível em: http://www.scielo.br/scielo. php?script=sci_arttext\&pid=S0011-52582005000200005. Acesso em: 18/12/2019.

NASCIMENTO, E. O. O sistema de comissões brasileiro: elementos para uma agenda de pesquisa. Teoria \& Pesquisa: Revista de Ciência Política, São Carlos-SP, v. 21, n.2, p. 61-72, jul./dez. 2012. Disponível em: http://www.teoriaepesquisa.ufscar.br/ index.php/tp/article/view/314/217. Acesso em: 18/12/2019.

NEIVA, P.; IZUMI, M. Os sem-voto do legislativo brasileiro: quem são os senadores suplentes e quais os seus impactos sobre o processo legislativo. Opinião Pública, Campinas, v. 18, n.1, p.1-21, jun. 2012. Disponível em: http://www.scielo.br/ scielo.php?script=sci_arttext\&pid=S0104-62762012000100001. Acesso em: 18/12/2019. 
SOUZA E SILVA, Jonatas N. A. A comissão de direitos humanos e legislação participativa (CDH) no senado brasileiro: um estudo sobre sua composição (2005-2018). Caos - Revista Eletrônica de Ciências Sociais, João Pessoa, n. 23, p. 79 -112, jul./dez. 2019. Disponível em: https://periodicos.ufpb.br/ojs2/index.php/caos/index.

PEREIRA, C; MUELLER, B. Uma teoria da preponderância do poder executivo: o sistema de comissões no legislativo brasileiro. Revista Brasileira de Ciências Sociais, São Paulo, v. 15, n. 43, p. 45-67, jun. 2000. Disponível em: http://www.scielo.br/scielo. php?script=sci_abstract\&pid=S0102-69092000000200004\&lng=en\&nrm=iso\&tlng=pt. Acesso em: 18/12/2019.

POWER, Timothy. Presidencialismo de coalizão e o design institucional brasileiro: o que sabemos até agora? In: SATHLER, André; BRAGA, Ricardo. Legislativo pós-1988: reflexões e perspectivas. Brasília: Edições Câmara, 2015, p. 15-46.

RUBIATTI. B. C. Sistema de resolução de conflitos e o papel do Senado como câmara revisora no bicameralismo brasileiro. Revista Brasileira de Ciência Política, Brasília, n.23, p. 35-74, 2017. Disponível em: http://www.scielo.br/scielo.php?script=sci_abstract \&pid=S0103-33522017000200035\&lng=en\&nrm=iso\&tlng=pt. Acesso em: 18/12/2019.

SANTOS, Fabiano. Partidos e comissões no presidencialismo de coalizão. Dados, Rio de Janeiro, v. 45, n. 2, p. 237-264, 2002. Disponível em: http:// www.scielo.br/scielo.php?script=sci_arttext\&pid=S0011-52582002000200003\&lng=e n\&nrm=iso. Acesso em: 18/12/2019.

SANTOS, F; ALMEIDA, A. Fundamentos informacionais do presidencialismo de coalizão. Curitiba: Appris, 2011.

Recebido em: 17/09/2019.

Aceito em: 08/11/2019. 